\title{
Enduring Principle: On Race, Process, and Constitutional Law
}

\author{
Barbara J. Flagg †
}

\section{INTRODUCTION}

When President Clinton withdrew his nomination of Lani Guinier to be Assistant Attorney General for Civil Rights, he said it was because some of her writings "lend themselves to interpretations that do not represent the views that I expressed on civil rights during my campaign and views that I hold very dearly ...." Asked to elaborate on the portions of her writing that he found troublesonie, the President singled out Guinier's proposals concerning proportional representation and minority veto. He commented: "the whole thrust of that kind of argument, it seems to me, is inconsistent with the arguments that I tried to make to members of all races all during my campaign."2

As I interpret the President's explanation, he seems to believe that the race-conscious, outcome-sensitive remedial measures proposed in Lani Guinier's articles violate a principle of colorblindness - the view that race should not matter in assessing an individual, and so government should not take it into account in official decisionmaking. ${ }^{3}$ If this reading is correct, then withdrawing her nomination demonstrated that the President was willing to impose very significant costs on a black woman and on the public, for the sake of a principle. Ms. Guinier suffered all the pain associated with being in the position of a silenced political target. ${ }^{4}$ The public lost an opportunity to have the Civil Rights Division headed by an exceptionally able, experienced, and committed civil rights attorney. It seems a very great deal to endure for the sake of an abstraction.

Copyright (C) 1994 Califomia Law Review, Inc.

$\dagger$ Associate Professor of Law, Washington University, St. Louis. I thank Susan Appleton, Dayna Deck, Kathy Goldwasser, Richard Lazarus, Dan Keating, Robert Post, and Peter Wiedenbeck for helpful comments on earlier drafts of this Article; any remaining errors are entirely my own.

1. Remarks Announcing Withdrawal of the Nomination of Lani Guinier and an Exchange With Reporters, 29 Weekly Comp. Pres. Doc. 1027, 1027 (June 3, 1993).

2. Id. at 1028 .

3. President Clinton's position may be only that one should not take race into account in the outcome-oriented manner Guinier suggested, but I extrapolate to the broader conception of colorblindness because that principle is widely accepted in society at large.

4. An intriguing account of the way the Guinier nomination was targeted by the "right wing"and of the administration's delayed and inadequate response to the campaign-can be found in Karen Branan, Lani Guinier: The Anatomy of a Betrayal, Ms., Sept.-Oct. 1993, at 51. 
Of course, sacrificing individual interests is part of what it means to stand by one's principles. However, in this case a white man set aside not his own interests, but those of a black woman. And though I include myself, a white woman, in the category of those who are metaphorically poorer for the loss of Guinier, there can be little doubt that strong leadership of the Civil Rights Division is more important for black people generally than it is for me or for other white people. In short, Clinton's sacrifice was the sacrifice of predominantly black interests. ${ }^{5}$

Viewed in that light, the Lani Guinier episode is a paradigm of the way white people allow "principle" to subvert racial justice. ${ }^{6}$ It exemplifies a distinctive inflexibility in our approach to racially-charged problems-an inflexibility that comes into play, more often than not, when non-white interests are at stake. This Article seeks to examine another instance of intellectual rigidity in the face of racial injustice: the impact of a particular constellation of process-oriented values on the development of constitutional race discrimination law.

The processual ${ }^{7}$ principles with which this Article is concerned arise out of two distinct jurisprudential traditions. The first tradition is one of judicial restraint: it holds that the (unelected) judiciary ought to defer to legislative policy choices, absent special justification for judicial intervention. The second strand of the process perspective, a concern with institutionally appropriate decisionmaking procedures, has its roots in the Legal Process school of the 1940s and 1950s. In constitutional law, this aspect of the process orientation directs one's analytic attention to the nature and proper functioning of judicial and legislative processes of decisionmaking.

The process perspective has become so thoroughly embedded in the landscape of constitutional doctrine that analysts do not always pay sufficient attention to the influence it exerts on the development of specific doc-

5. I don't mean to suggest that all black people, or members of any racially-identifiable group, share the same interests or perspectives. See generally Angela P. Harris, Race and Essentialism in Feminist Legal Theory, 42 StAN. L. REv. 581 (1990). However, rejecting essentialism does not mean that one may never make roughly accurate generalizations about groups or their interests.

6. Of course, one's understanding of what racial justice requires depends in large part on the principles to which one adheres, so in one sense a particular conception of racial justice can be subvertcd only through allegiance to a different principle than the one that defines that conception. However, the connection between principles and concepts of racial justice is part of the problem to whieh this Article is addressed: white people seem to have a tendency to assert, and stand by, principles that purport to have desirable real-world consequences, without carefully examining whether those consequenccs do occur in fact.

7. "Processual" is defined as "of or relating to a legal process." WEBSTER's ThIRD New INTERNATIONAL Dictionary of the ENGLish LaNGUaGe, UNabridoed 1808 (1986). Some further clarification of terminology may be in onder. The package of process-oriented values that is the principal subjeet of this Article will be called the "process perspective," "process-oriented jurisprudence," and the like. These are general terms whose scope includes the appearance of process values in constitutional doctrine and theory alike. "Process theory" refers to the broad category of constitutional theories that rest, in important ways, on one or both of the process principles described in the text; the Legal Process school of the 1940s and 1950s is a subset of the larger category of process theories. 
trinal positions. It is "just there," providing the background for virtually all post-Lochner constitutional analysis. ${ }^{8}$ For this reason alone, it would be worthwhile to engage in a closer-than-usual examination of the doctrinal impact of processual values. However, in the area of race discrimination doctrine, there is a more pressing consideration-the sorry state of current law.

I argue in this Article that the impact of the process perspective on constitutional race discrimination doctrine has not been salutary. The fact that the process orientation aims at targets other than racial justice has been apparent from the time of Brown v. Board of Education, ${ }^{9}$ when some process theorists were among the ruling's most vocal critics, generally in spite of their personal approval of the decision. As post-Brown constitutional doctrine has unfolded, the pattern has been repeated: processual considerations operate to counteract the evolution of doctrines that might genuinely benefit non-whites, though proponents of process values continue to express approval of the substantive goal of racial justice. Process principles consistently have been elevated above measures that promise to address the continuing reality of race inequality.

The incongruence between the intellectual trajectories of process theory and effective legal responses to racial inequities may be traced to another factor: process theory itself is race-specific. Elsewhere, I have developed what I call the "transparency thesis": the observation that white people tend to relegate "whiteness" to the realm of the subconscious. ${ }^{10} \mathrm{We}$ tend to perceive whiteness, and its associated characteristics and behaviors, as "neutral." Nevertheless, white people are not raceless, and characteristics associated with us are not necessarily race-neutral; the race-specificity of whiteness may be transparent, but it is not therefore nonexistent. Upon examination, the process perspective appears to be transparently white.

In general, recognizing transparency raises the problem of assimilationism: one must decide whether the values served by a transparently white norm justify imposing it on individuals who do not ascribe to those values. In the case of process theory, however, one does not have to reach that question, because the processual approach does not deliver the neutrality it promises. Therefore, the assimilationist costs of the process perspective are not justified.

This Article attempts to make the case for, and to examine the implications of, the two claims outlined above: first, that the process perspective has had a negative impact on the evolution of constitutional race discrimination law, as measured from the perspective of racial justice; and second,

8. Lochner v. New York, 198 U.S. 45 (1905), overruled by Day-Brite Lighting, Inc. v. Missouri, 342 U.S. 421 (1952). See infra notes 17-20 and accompanying text.

9. 347 U.S. 483 (1954).

10. Barbara J. Flagg, "Was Blind, But Now I See": White Race Consciousness and the Requirement of Discriminatory Intent, 91 Mich. L. Rev. 953, 969-79 (1993). 
that process-oriented jurisprudence is transparently, and unjustifiably, white. Part I describes the historical antecedents of the process perspective. Part II then assesses the impact of the process perspective on constitutional race discrimination doctrine. I focus on two generic strands of the process approach - the perceived importance of justifying judicial review, and the emphasis on questions of institutional competence in constitutional analysis. I argue that these impulses have affected the development of two central constitutional doctrines - the requirement of discriminatory intent in disparate impact cases, and the rule requiring strict scrutiny of all racespecific government action. I contend that the influence of the process perspective on these doctrines has been in a direction adverse to the interests of substantive racial justice.

Part III sets forth the proposition that process theory is transparently white. I begin with a summary of the transparency thesis, particularly as applied to the analysis of ostensibly race-neutral criteria of decision. I then extend the transparency thesis to the realm of theory, and in so doing consider possible criteria that might be used to evaluate whether a theory or intellectual paradigm is "white." I conclude that process theory should be assessed as "white" in each of the relevant senses. Finally, I conclude that because the neutrality promised by processualism is not realized, the process perspective cannot be justified as serving larger, albeit assimilationist values. Accordingly, the process perspective should not occupy the preferred position in constitutional discourse it currently enjoys.

\section{I}

\section{Antecedents of the Process Perspective}

As I use the term, the process perspective incorporates two distinct themes. One is a principle of "judicial restraint" or judicial deference to legislative authority. This principle resolves the question of how authority should be allocated among decisionmaking institutions. ${ }^{11}$ The second theme addresses matters of procedural regularity within a given institution, and pays particular attention to the nature of the institution under evaluation. This Part describes, and attempts to provide some historical context for, these two strands of process-oriented jurisprudence.

11. This characterization of the principle of judicial restraint highlights one way in which it dovetails with the institutional concems of process theory, but one should be careful not to overstate the connection. As discussed in Parts I.A and I.B infra, the two themes developed somewhat independently of each other. 


\section{A. The Principle of Judicial Restraint}

The Lochner era ${ }^{12}$ was an unprecedented period of judicial activism: between 1899 and 1937 the Supreme Court invalidated almost 200 state and federal statutes and regulations. ${ }^{13}$ The Court's activist stance generated intense political and intellectual opposition. Politically, the Court's invalidation of key New Deal legislation threatened emerging Roosevelt administration policies. ${ }^{14}$ This aspect of the problem was resolved in relatively short order, however. The "switch-in-time"15 that signaled the close of the Lochner era was followed by a series of Roosevelt appointments ${ }^{16}$ that effectively foreclosed any possible resurgence of the Lochner approach.

On the intellectual front, two distinct accounts of the errors of the Court's Lochner era jurisprudence emerged. ${ }^{17}$ One clrallenged the substantive premises on which the decisions of that period had rested, with particular emphasis on the Court's failure to engage in a meaningful analysis of existing unequal distributions of wealth and power. ${ }^{18}$ The second criticism was an institutional one: the Court should not have substituted its judgment for that of the legislature with regard to controversial value choices. ${ }^{19}$ The

12. For overviews of this period, see Paul L. Murphy, The Constrtumon In Crisis Times 19181969, at 41-67 (1972); Benjamin F. Wright, The Growth of American Constitutional Law 15370 (1942).

13. Laurence H. Tribe, American Constitutional Law 567 \& n.2. (2d ed. 1988). Tribe notes, however, that an even greater number of regulations survived review during this period. Id.; see also Morton J. Horwitz, History and Theory, 96 YALE L.J. 1825, 1827 (1987) (pointing out that the substantive premises of the Lochner era were entirely consistent with earlier constitutional ideology).

14. During 1935 and 1936 , the Court announced eleven decisions in which crucial federal legislative provisions were held unconstitutional. WRIGHT, supra note 12 , at 180-82 \& nn.1-13. In 1937 President Roosevelt proposed to Congress a "Court-packing" plan that would have added to the total number of Justices on the Supreme Court one additional Justice for each sitting Justice who had reached the age of 70 , ostensibly on the ground that the older Justices were unable to keep up with the Court's workload. The plan was generally understood to be designed to create a Court majority who would vote to uphold Roosevelt's New Deal legislation. William E. Leuchtenburg, The Origins of Franklin D. Roosevelt's “Court-Packing" Plan, 1966 Sup. Cr. Rev. 347, 387-400.

15. Justice Roberts, who provided the fifth vote to uphold a minimum wage statute in West Coast Hotel v. Parrish, 300 U.S. 379 (1937), is often thought to have changed his views in response to the Court-packing plan. However, a memorandum written by Justice Roberts shows that an initial vote in West Coast Hotel was taken several weeks before the President's plan was announced. See Felix Frankfurter, Mr. Justice Roberts, 104 U. PA. L. Rev. 311, 313-15 (1955).

16. By the end of 1939, President Roosevelt had nominated, and the Senate had confirmed, four new Justices: Hugo L. Black (replacing Willis Van Devanter, who retired in 1937 during Congress" debate over the Court-packing plan); Stanley F. Reed (replacing George Sutherland, who retired in 1938); Felix Frankfurter (replacing Benjamin N. Cardozo, who died in 1938); and William O. Douglas (replacing Louis D. Brandeis, who retired in 1939). Roosevelt later named to the Court Justices Murphy (1940), Bymes (1941), Jackson (1941), and Rutledge (1943), and he nominated Justice Harlan F. Stone to be Chief Justice in 1941. See Gerald Gunther, Constrtutronal Law B-5 to B-6 app. B (12th ed. 1991) (Table of Justices).

17. Horwitz, supra note 13 , at 1829 .

18. See, e.g., Morris R. Cohen, Property and Sovereignty, 13 CoRNELL L.Q. 8 (1927); Robert L. Hale, Coercion and Distribution in a Supposedly Non-Coercive State, 38 PoL. Scr. Q. 470 (1923); Roscoe Pound, Liberty of Contract, 18 YALE L.J. 454 (1909); see also Horwitz, supra note 13, at 1829.

19. Horwitz, supra note 13, at 1829; see, e.g., Ferguson v. Skrupa, 372 U.S. 726, 728-31 (1963); Williamson v. Lee Optical of Oklahoma, Inc., 348 U.S. 483, 488 (1955); Lochner v. New York, 198 
latter understanding of the Lochner era has come to dominate constitutional theory and doctrine. ${ }^{20}$

The institutional criticism of the Lochner Court drew upon a preexisting line of arguments advocating judicial restraint. In 1893, James B. Thayer argued in his influential paper The Origin and Scope of the American Doctrine of Constitutional Law ${ }^{21}$ that courts should exercise the power of judicial review only "when those who have the right to make laws have not merely made a mistake [regarding constitutionality], but have made a very clear one,--so clear that it is not open to rational question."22 In Thayer's view, the constitutional text is open to a variety of interpretations. While each of the political branches has an obligation to make a judgment concerning the constitutionality of its own behavior, the coordinate branches of government would be unable to function together unless each respected the authority of the others to act upon reasonable interpretations of their constitutional mandates. Therefore, a legislative judgment that a particular enactment is constitutional is entitled to judicial respect unless the legislature's assessment is clearly erroneous. ${ }^{23}$ In addition, Thayer suggested that legislatures were more competent than courts to make policy, ${ }^{24}$ and that too frequent invalidation of legislative acts might undermine the legislature's will to engage seriously with "questions of justice and right." 25

Thayer's principle of judicial restraint exerted a profound influence on the judicial philosophies of Justices Holmes, Brandeis, and Frankfurter. ${ }^{26}$ Their written opinions at times reflected an additional argument in favor of judicial restraint: the image of the judiciary as a "non-democratic" institution. ${ }^{27}$ For example, in 1949 Justice Frankfurter contended that:

U.S. 45, 74-76 (1905) (Holmes, J., dissenting). Laurence Tribe notes a third possibility in addition to the two described in the text: the Court could have accepted the pluralist philosophy that no public interest exists beyond that which is revealed through the summation of private interests in the poititical process, and so eschewed review of legislative decisions on that basis. TRIBE, supra note 13, at 582-83.

20. TRIBE, supra note 13, at 583; Horwitz, supra note 13, at 1829-30; Cass R. Sunstein, Lochner's Legacy, 87 Colum. L. REv. 873, 874 (1987).

21. James B. Thayer, The Origin and Scope of the American Doctrine of Constitutional Law, 7 HaRv. L. REv. 129 (1893).

22. Id. at 144 .

23. See id. Thayer did not extend this principle of judicial restraint to federal court review of the constitutionality of state legislation, because the institutional relationship between those bodies is different in character. More aggressive review of state legislation is in order, because in those instances the judiciary "speaks as representing a paramount constitution and government ...." Id. at 154-55.

24. See id. at 152.

25. See id. at 155-56.

26. Wallace Mendelson, The Influence of James B. Thayer upon the Work of Holmes, Brandeis, and Frankfurter, 31 VAND. L. Rev. 71 (1978). Each of these Justices acknowledged Thayer's role. Id. at 73.

27. Historians have attributed this argument, and the insistence with which it was advanced, to the political influence of the Progressive movement. See Morton J. Horwitz, The Transformation of AMERICAN LAW, 1870-1960, at 261 (1992); MURPHY, supra note 12, at 70-82; Horwitz, supra note 13, at 1830 . The democracy-based argument for judicial restraint also has been characterized as a response 
In the day-to-day working of our democracy it is vital that the power of the non-democratic organ of our Government be exercised with rigorous self-restraint. Because the powers exercised by this Court are inherently oligarchic, Jefferson all of his life thought of the Court as "an irresponsible body" and "independent of the nation itself." The Court is not saved from being oligarchic because it professes to act in the service of humane ends. ${ }^{28}$

This version of the principle of restraint has been developed more fully in the academic literature. ${ }^{29}$ In Alexander Bickel's classic statement, for instance, the power of judicial review should be exercised with caution because of the "counter-majoritarian" character of the judiciary: "[W]hen the Supreme Court declares unconstitutional a legislative act or the action of an elected executive, it thwarts the will of representatives of the actual people of the here and now; it exercises control, not in behalf of the prevailing majority, but against it." 30

Taken together, these arguments constitute a case for judicial restraint that dominates the landscapes of mainstream constitutional theory and doctrine to this day. ${ }^{31}$ In both realms, advocates of judicial review generally perceive a need to confront and overcome the "legitimacy" question. ${ }^{32}$ Part II.A of this Article explores the impact that this presumption against exercising the power of judicial review has had on the development of constitutional doctrine regarding disparate impact race discrimination cases.

The reader may be left, however, with a taxonomic question: to the extent that the principle of restraint rests on the "counter-majoritarian diffi-

to the rise of fascism in Europe. See Edward A. Purcell, JR., The Crisis of Democratic Theory 218-31 (1973).

28. American Fed'n of Labor v. American Sash \& Door Co., 335 U.S. 538, $555-56$ (1949) (Frankfurter, J,, concurring) (footnotes omitted).

29. Although Learned Hand placed less emphasis on the concept of democracy, I include his 1958 lectures at Harvard University in this category. See Learned Hand, The Bill of Rights: The Oliver WeNDEll Holmes Lectures 1958, at 73-74 (1958) (expressing a preference for democracy, rather than government by a "bevy of Platonic Guardians").

30. Alexander M. Bickel, The Least Dangerous Branch: The Supreme Court at the Bar of Polmtics 16-17 (1962). Bickel saw Thayer's rule of restraint as "aim[ing] at accommodation with the theory of representative democracy," id. at 40 , but Bickel's reading seems to be mistaken, if he means to attribute the "counter-majoritarian" argument to Thayer. One obvious way in which Bickel's and Thayer's approaches to judicial restraint diverge is that Bickel's analysis, unlike Thayer's, applies equally to state and federal legislatures. Id. at 33.

31. TRIBE, supra note 13 , at 584 .

32. See, e.g., Jesse H. Choper, Judicial Review and the National Polmtical Process: A Functional Reconsideration of the Role of the Supreme Court 4-59 (1980); John Hart Ely, Democracy and Distrust: A Theory of Judictal Review 4-7 (1980); Michael J. Perry, The Construmton, The Courts, and Human Richts $2-4$ (1982). Of course, rights-based constitutional theories minimize or reject the importance of the "counter-majoritarian difficulty." See, e.g., Paul Brest, The Fundamental Rights Controversy: The Essential Contradictions of Normative Constitutional Scholarship, 90 Yale LJ. 1063, 1064-65 (1981); G. EDWARD WhITE, Chief Justice Marshall, Justice Holmes, and the Discourse of Constitutional Adjudication, in INTERVENTION AND DETACHMENT: EsSAYS in Legal HIstory and JuRIsprudence 238 (1994) (describing "Marshallian" and "Holmesian" approaches to constitutional interpretation). 
culty," it seems to be a matter of substance rather than process, because that formulation presupposes a particular political conception of the role of the courts in a constitutional democracy. ${ }^{33}$ On the other hand, the political theory in question is processual in another sense: it relies on democratic processes to resolve the problem of selecting among competing societal values. For that reason, I subsume the principle of judicial restraint under the general heading of the "process perspective." 34

\section{B. Assessing Institutionally Appropriate Processes}

The 1940s and 1950s saw the development of a school of jurisprudence that came to be labeled the Legal Process School. ${ }^{35}$ Its emergence can be understood as a response to the implicit moral relativism of Legal Realism. ${ }^{36}$ Legal Process theorists found a source for the legitimacy of law independent of its normative content in the distinction between process and

33. More precisely, this argument incorporates two propositions: that democracy means decision by popular majority, and that courts are relatively less responsive to majority will than other government institutions. Both are contestable. See, e.g., William R. Bishin, Judicial Review in Democratic Theory, 50 S. CaL. L. Rev. 1099 (1977); Eugene V. Rostow, The Democratic Character of Judicial Review, 66 HARV. L. REV. 193 (1952).

34. This is not an unusual characterization of the "democratic theory" approach to judicial restraint. See, e.g., HoRwrT, supra note 27, at 255-56 (describing "process-orientcd theory of democracy"); G. EDWARD WHTTE, The Evolution of Reasoned Elaboration: Jurisprudential Criticism and Social Change, in Patterns of American Legal Thought 136, $149-50$ (1978) (including within the "Reasoned Elaboration" tradition's expectations regarding judicial behavior that "rested on the premise that the judiciary was not a representative or democratic institution and should not encroach upon the prerogatives of the popularly elected branches"); Bruce A. Ackerman, Book Revicw, 103 DaEdalus 119, 123-24 (1974) ("The Legal Process School sees the articulation of social philosophy as a task for the political, not the judicial, process because the executive and the legislature, unlike the courts, are directly responsible to the people through the democratic process.").

35. An account of the various uses of the term "process" in this Article has been provided supra note 7.

For descriptions of, and commentary on, process theory in the generic sense, see HoRwiTz, supra note 27, at 253-58; Elizabeth Mensch, The History of Mainstream Legal Thought, in THE Potitics of Law: A Progressive Critique 13, 24-33 (David Kairys ed., rev. ed. 1990); G. Edward White, The American Judicial Tradition 230-96 (1976); White, supra note 34, at 136-63; Gary Peller, Neutral Principles in the 1950's, 21 U. Mich. J.L. REF. 561 (1988); Terrance Sandalow, Judicial Protection of Minorities, 75 Mich. L. Rev. 1162 (1977); Joseph W. Singer, Legal Realism Now, 76 Calif. L. Rev. 465, 505-08 (1988) (book review).

36. The Legal Realists challenged the traditional faith in the objective existence of "rights" as well as traditional legal methodology. They asserted, inter alia, that rights were not a preexisting fact of nature but instead were a function of (largely arbitrary) legal decisionmaking, Mensch, supra note 35, at 21-22, and that there were consequently no moral or ethieal absolutes with which to evaluate law, Peller, supra note 35, at 580. A classic example of Realist analysis can be found in George D. Braden, The Search for Objectivity in Constitutional Law, 57 YALE L.J. 571 (1948).

Helpful overviews of Legal Realism can be found in Horwrrz, supra note 27, at 169-212; Purcell, supra note 27, at 74-94; Wilfrid E. Rumble, JR., American Legal Realism (1968); White, From Sociological Jurisprudence to Realism: Jurisprudence and Solid Change in Early TwentiethCentury America, in Patterns of American Legal Thought, supra note 34, at 99-135; Mensch, supra note 35, at 21-24; Gary Peller, The Metaphysics of American Law, 73 CaLIr. L. REv. 1151, 1219. 59 (1985); Edward A. Purcell, Jr., American Jurisprudence Between the Wars: Legal Realism and the Crisis of Democratic Theory, 75 AM. Hist. Rev. 424 (1969); Singer, supra note 35, at 468-95; William Twining, Talk About Realism, 60 N.Y.U. L. REv. 329 (1985). 
substance: if the implication of moral relativism was that law could not be legitimated by reference to its substantive content, one might nevertheless discover a source of authority in law's "institutionalized procedures for the settlement of questions of group concern." ${ }^{37}$ Lon Fuller's The Morality of Law represents an early entry im this project of reconstruction:

What I have tried to do is to discern and articulate the natural laws of a particular kind of human undertaking, which I have described as "the enterprise of subjecting human conduct to the governance of rules." These natural laws have nothing to do with any "brooding omnipresence in the skies." ... They are like the natural laws of carpentry, or at least those laws respected by a carpenter who wants the house he builds to remain standing and serve the purpose of those who live in it.

As a convenient (thought not wholly satisfactory) way of describing the distinction being taken we may speak of a procedural, as distinguished from a substantive natural law. What I have called the internal morality of law is in this sense a procedural version of natural law, though to avoid misunderstanding the word "procedural" should be assigned a special and expanded sense so that it would include, for example, a substantive accord between official action and enacted law. The term "procedural" is, however, broadly appropriate as indicating that we are concerned, not with the substantive aims of legal rules, but with the ways in which a system of rules for governing human conduct must be constructed and administered if it is to be efficacious and at the same time remain what it purports to be. ${ }^{38}$

The work of Henry Hart and Albert Sacks was perhaps the most comprehensive attempt to elaborate the theoretical insights of the Process school. In The Legal Process, they set forth an analysis of institutional procedures organized around what they called "the principle of institutional

37. Henry M. Hart, Jr. \& Albert M. Sacks, The Legal Process: Basic Problems in the Making AND Application of LAw 3 (tentative ed. 1958) (emphasis in original). The characterization of Legal Process jurisprudence as a search for "legitimacy" is inferential: these process theorists themselves framed the issue as the problem of the "is" and the "ought":

[T] principle of institutional settlement is plainly applicable, we say that the law "is" thus and so, and brush aside further discussion of what it "ought" to be. Yet the "is" is not really an "is" but a special kind of "ought"-a statement that ... a decision which is the duly arrived at result of a duly established procedure for making decisions of that kind "ought" to be accepted as binding upon the whole society unless and until it has been duly changed.

Id. at 4-5 (emphasis in original).

For elaboration of the analysis of the Legal Process school as engaged in a search for valueindependent legitimacy, see WHITE, supra note 34, at 143-44; WhITE, supra note 32, at 281; Mensch, supra note 35, at 25; Peller, supra note 35, at 569.

38. Lon L. Fuller, The Moraltry of Law 96-97 (rev. ed. 1969). 
settlement." 39 Their basic notion was that for each sort of dispute or substantive question there was some procedure particularly suited as the mechanism for its resolution; the institutional approaches they considered included private ordering, legislation, administrative regulation, executive regulation, and judicial decisionmaking in the common law and statutory interpretation contexts. ${ }^{40}$ In the course of developing this procedural matrix, Hart and Sacks identified the institutional competence that characterized each institution and made it unique. ${ }^{41}$ Thus, for example, the special competence of the legislature lay in its ability to resolve general questions of substantive value in a democratic manner; the competence of administrative agencies was found in the notion of agency expertise, and so forth. In Hart and Sacks' view, the specific characteristics of each institution determined the type of issue that ought to be committed to it for resolution.

Hart and Sacks did not address the problem of constitutional review; that territory was covered by Herbert Wechsler in his well-known article, Toward Neutral Principles of Constitutional Law. ${ }^{42}$ Wechsler's analysis in Neutral Principles accepted the institutional legitimacy of judicial review only if it rested on "reasons with respect to all the issues in the case, reasons that in their generality and their neutrality transcend any immediate result that is involved."43 The precise contours of the "neutrality" requirement are far from clear, ${ }^{44}$ but one can be confident of one point: in Wechsler's view,

39. HART \& SACKS, supra note 37, at 4. Further description and evaluation of these materials can be found in William N. Eskridge, Jr. \& Philip P. Frickey, Legislation Scholarship and Pedagogy in the Post-Legal Process Era, 48 U. Prrt. L. Rev. 691, 694-701 (1987); Peller, supra note 36, at 1183-87; Peller, supra note 35 , at 568-72.

40. HART \& SACKS, supra note 37.

41. Id. at 3 (stating that "different procedures and personnel of different qualifications invariably prove to be appropriate for deciding different kinds of questions").

42. Herbert Wechsler, Toward Neutral Principles of Constitutional Law, 73 Harv. L. Rev. 1 (1959). Wechsler delivered Neutral Principles as the 1959 Oliver Wendcll Holmes Lectures at Harvard Law School. Unlike Judge Leamed Hand, who had delivered the lectures the previous year, Wcchsler believed that judicial review was authorized by the text of the Constitution. At the same time, however, he made it clear that the power of judicial review was to be constrained by the "neutral principles" requirement. See id. at 16.

43. Id. at 19.

44. Some commentators read Neutral Principles to state little more than a requirement of generality and uniformity, see Wrrre, supra note 34, at 147-48; Kent Greenawalt, The Enduring Significance of Neutral Principles, 78 Colum. L. REv. 982, 985-90 (1978), but others see it as an attempt to articulate a value-free method of constitutional decisionmaking, see, e.g., Arthur S. Miller \& Ronald F. Howell, The Myth of Neutrality in Constitutional Adjudication, 27 U. CHr. L. REv. 661 (1960); Peller, supra note 35. Most commentators express unccrtainty, however. See Brcket, supra note 30, at 50-59; Jan G. Deutsch, Neutrality, Legitimacy, and the Supreme Court: Some Intersections Between Law and Political Science, 20 STAN. L. REv. 169, 178-97 (1968); Addison Mueller \& Murray L. Schwartz, The Principle of Neutral Principles, 7 UCLA L. Rev. 571 (1960); Louis H. Pollak, Racial Discrimination and Judicial Integrity: A Reply to Professor Wechsler, 108 U. PA. L. Rev. 1 (1959); David A.J. Richards, Rules, Policies, and Neutral Principles: The Search for Legitimacy in Common Law and Constitutional Adjudication, 11 GA. L. REv. 1069, 1082-89 (1977).

Subsequently, Wechsler himself provided some elaboration:

In calling for neutrality of principle, I certainly do not deny that constitutional provisions are directed to protecting certain special values or that the principled development of a particular 
the criterion of "reasoned elaboration" 45 followed from the nature of the judicial process itself. ${ }^{46}$ Analysis of the judicial function provided his answer to the question "what, if any, are the standards to be followed in [constitutional] interpretation."47

Though it was not formulated as a response to the "countermajoritarian difficulty," Wechsler's version of the requirement of reasoned elaboration militates in favor of judicial restraint: the judiciary should defer to legislative judgment unless the "neutral principle" mandate can be satisfied. ${ }^{48}$ However, one of the Court's early post-Lochner opinions had sown

provision is concerned with the value or the values thus involved. The demand of neutrality is that a value and its measure be determined by a general analysis that gives no weight to accidents of application, finding a scope that is acceptable whatever interest, group, or person may assert the clain. So too, when there is conflict among values having constitutional protection, calling for their ordering or their accommodation, I argue that the principle of resolution must be neutral in a comparable sense (both in the definition of the individual coinpeting values and in the approach that it entails to value coinpetition).

Herbert Wechsler, Principles, Polmics, and Fundamental Law xiii-xiv (1961).

It may seem to some that this passage puts to rest the "value-free" interpretation of Neutral Principles, but that is not unambiguously the case. There still remains the argument that concepts of generality and consistency of application cannot account for Wechsler's disapproval of the Brown decision. This point will be discussed further infra at notes 133-144 and acconipanying text. Wechsler's position, in the end, seems to have been one of contentment with the difficulty: "[T] rest on "general," [rather than "neutral,"] is to give up overtones that I intend. That those overtones are somewhat eniginatic in their content is not, from my point of view, a real deficiency; this is an enigmatic subject." WECHSLER, supra at xiii.

45. The term was coined by Hart and Sacks. HaRT \& SACKs, supra note 37, at 161. See also WHITE, supra note 34 , at 144.

46.

[W] hat is crucial, I submit, is not the nature of the question but the nature of the answer that inay validly be given by the courts. No legislature or executive is obligated by the nature of its function to support its choice of values by the type of reasoned explanation that $I$ have suggested is intrinsic to judicial action-however much we may admire such a reasoned exposition when we find it in those other realms.

Wechsler, supra note 42 , at 15-16.

47. Id. at 10-11.

During the 1950s a succession of Forewords to the Harvard Law Review's annual review of the preceding Supreme Court term critiqued the Court's decisions in the inanner approved by Wechsler. See, e.g., Alexander M. Bickel \& Harry H. Wellington, Legislative Purpose and the Judicial Process: The Lincoln Mills Case, 71 Harv. L. Rev. 1 (1957) (criticizing the Court for its failure to state rationally articulated grounds of decision); Emest J. Brown, The Supreme Court, 1957 TermForeword: Process of Law, 72 HaRv. L. Rev. 77 (1958) (criticizing the Court's use of summary adjudications of cases in which it grants certiorari); Henry M. Hart, Jr., The Supreme Court, 1958 Term-Foreword: The Time Chart of the Justices, 73 HARv. L. REv. 84, 99 (1959) (arguing that the Court should try to decide fewer cases by full opinion, because "[0]nly opinions which are grounded in reason and not on mere fiat or precedent can do the job which the Supreme Court of the United States has to do"); Louis L. Jaffee, The Supreme Court, 1950 Term-Foreword, 65 HARv. L. Rev. 107, 113-14 (1951) (contending that the Court was subject to some criticism for its lack of institutional awareness and pride, perhaps to "an overstressing by 'realists' and 'liberals' of the political function of the Court"); Albert M. Sacks, The Supreme Court, 1953 Term-Foreword, 68 HARV. L. REv. 96 (1954) (criticizing the Court's lack of explanation in its per curiam decisions).

48. Wechsler, supra note 42 , at 25. Jan Deutsch argued that Wechsler's concept of neutral principles might have been a response to the perceived undemocratic nature of courts. See Deutsch, supra note 44 , at $183-85$. 
the seeds of a processual justification for a more expanded range of judicial review. ${ }^{49}$

The well-known Carolene Products Footnote Four set forth three bases for non-deferential judicial review:

There may be narrower scope for operation of the presumption of constitutionality when legislation appears on its face to be within a specific prohibition of the Constitution, such as those of the first ten amendments, which are deemed equally specific when held to be embraced within the Fourteenth.

It is unnecessary to consider now whether legislation which restricts those political processes which can ordinarily be expected to bring about repeal of undesirable legislation, is to be subjected to more exacting judicial scrutiny under the general prohibitions of the Fourteenth Amendment than are most other types of legislation.

Nor need we enquire whether similar considerations enter into the review of statutes directed at particular religious, or national, or racial minorities: whether prejudice against discrete and insular minorities may be a special condition, which tends seriously to curtail the operation of those political processes ordinarily to be relied upon to protect minorities, and which may call for a correspondingly more searching judicial inquiry. ${ }^{50}$

The second and third paragraphs of Footnote Four provide the focus for "second generation" 51 process theory. 52 Wechsler's discussion of judicial review had centered on the particular characteristics of courts, omitting consideration of the problem of legislative competence. ${ }^{53}$ However, attention to instances in which the legislative process itself appeared to have broken down might lead to an institutional justification for more active judicial review, even if one accepted the argument that the democratic character

49. It should be noted that a precursor of the "political process" approach can be found as well in McCulloch v. Maryland, 17 U.S. (4 Wheat.) 316 (1819):

This opinion ... does not extend to a tax paid by the real property of the bank, in common with the other real property within the state, nor to a tax imposed on the interest which the citizens of Maryland may hold in this institution, in common with other property of the same description throughout the state.

Id. at 436 .

50. United States v. Carolene Prods. Co., 304 U.S. 144, 152-53 n.4 (1938) (citations omitted).

51. As I use the terms, first generation process theory is charactcrized by its focus on judicial competence and corresponding reliance on the notion of reasoned elaboration; the second (and third) generation versions emphasize the question of legislative competence. I'll also use the term "political process theory" in connection with the latter two variants of the process-theoretical approach. For a description of third generation process theory, see infra text accompanying notes 68-70.

52. While the second and third paragraphs of Footnote Four clearly set forth processual justifications for judicial review, the first paragraph appears to embody a different sort of justificationone that is purely textual. The evolution of Footnote Four supports the view that its first paragraph rests on a different theoretical foundation from the other two: paragraph one was added, at the suggestion of Chief Justice Hughes, after paragraphs two and three had been drafted. Louis Lusky, Footnote Redux: $A$ Carolene Products Reminiscence, 82 Colum. L. Rev. 1093, 1096-100 (1982).

53. Peller, supra note 35 , at $610-11$ \& n.67. 
of the legislature counseled presumptive judicial deference. In Democracy and Distrust, ${ }^{54}$ John $\mathrm{H}$. Ely elaborated on "access" and "prejudice" justifications for judicial review, which were derived from Footnote Four's second and third paragraphs, respectively. ${ }^{55}$

Ely's theory of judicial review revolves around the idea of "representation reinforcement." J6 Judicial interpretation of the constitution's "openended" provisions should be guided by the principle animating the document as a whole-representative democracy. When there is reason to believe that the processes of representative democracy are not operating as they should, judicial intervention is justified as a means of correcting the defect. In Ely's interpretation, paragraphs two and three of Footnote Four both address political process defects. ${ }^{57}$

The guiding principle of the second paragraph (the "access" prong) of Footnote Four is that the political process cannot be deemed to be operating properly-in Ely's analysis, to be genuinely representative-when segments of the population are excluded from formal participation in it. Thus, for Ely, judicial activism is justified in such circumstances in order to ensure that "the channels of political change" are kept clear. ${ }^{58}$ Specifically, heightened review is mandated for legislation impacting speech and voting rights, to ensure ongoing formal access to the political process for everyone. 59

The third paragraph (the "prejudice" prong) of Footnote Four embodies a somewhat different notion of political process defects. In Ely's words, "[t]he whole point of the approach is to identify those groups in society to whose needs and wishes elected officials have no apparent interest in attending."60 These are groups who are the objects of majoritarian prejudice, in the sense of hostility, or some forms of stereotyping, namely gener-

54. ELY, supra note 32. Commentary on Professor Ely's theory is much too extensive to list comprehensively. A broad range of views can be found in Raoul Berger, Government by Judiciary: Joln Hart Ely's "Invitation," 54 IND. L.J. 277 (1979); Samuel Estreicher, Platonic Guardians of Democracy: John Hart Ely's Role for the Supreme Court in the Constitution's Open Texture, 56 N.Y.U. L. REv. 547 (1981); Gary C. Leedes, The Supreme Court Mess, 57 Tex. L. REv. 1361, 1421-37 (1979); Symposium: Judicial Review versus Democracy, 42 Ono ST. L.J. 1 (1981); Symposium on Democracy and Distrust: Ten Years Later, 77 VA. L. Rev. 631 (1991); Mark Tushnet, Darkness on the Edge of Town: The Contributions of John Hart Ely to Constitutional Theory, 89 YALE L.J. 1037 (1980).

55. Before Democracy and Distrust, the "political process" approach had been outlined in short articles by Richard A. Givens, The Impartial Constitutional Principles Supporting Brown v. Board of Education, 6 How. L.J. 179 (1960) (arguing that judicial review was justified when the democratic process was threatened by segregation), and by Louis Lusky, Minority Rights and the Public Interest, 52 YALE L.J. 1, 20-21 (1942) (suggesting that courts must step in when the dislike of minorities renders the regular corrective political processes iueffective).

56. ELY, supra note 32, at 73-104.

57. It appears that Ely is drawn to a text-based theory of constitutional interpretation, but he sees that approach as ultimately unworkable because of what he calls the constitution's "open-ended" provisions. Id. at 13-14.

58. Id. at 105 .

59. Id. at 105-34.

60. Id. at 151 . 
alizations that reflect "us" and "them" social categories, and are employed in legislation to benefit "us." sense) represent process defects because they "distort[] reality."62 Prejudice can blind decisionmakers to the existence of shared interests; stereotyping can result in the systematic misapprehension of the costs and benefits of legislation that operates to disadvantage "them."63 Accordingly, judicial review is justifled as a means of cleansing the political process of the distorting effects of prejudice and stereotyping.

Though Ely's "political process" theory is driven by a desire to justify judicial review in the face of the counter-majoritarian difficulty, it has as well a significant link with the Legal Process school of the 1950s-the emphasis on analyses of institutional competence. In Ely's approach, one assesses legislative processes in order to determine whether judicial review is in order. ${ }^{64}$ Thus, at a general level of characterization, the sole difference between Ely's and first generation process theories is the identity of the institution under examination. In this sense, Ely's theory of judicial review represents a natural evolution of process theory. 65

However, a number of commentators have argued quite persuasively that Ely's approach is not genuinely processual, because the "prejudice" prong of Footuote Four cannot be implemented without recourse to substantive value choices. ${ }^{66}$ In brief, the contention is that one must have some substantive conception of "prejudice" in order to decide when judicial intervention is warranted. In this respect, Footnote Four's third paragraph, and Ely's elaboration of it, fall short of realizing one of the central aspirations of process theory-the desire to find a value-neutral foundation for the legitimacy of law's commands. ${ }^{67}$

There remains the "access" prong of Footnote Four, which identifies a role for judicial review in correcting defects in formal access to political

61. Id. at 153-60.

62. Id. at 153 .

63. Moreover, Ely regards as unconstitutional per se the desire to harm a group just for the sake of the harm itself. Id. In contrast, Cass Sunstein argues that the view that "naked preferences" are not permissible government purposes is not process-based. Cass R. Sunstein, Public Values, Private Interests, and the Equal Protection Clause, 1982 Sup. Cr. Rev. 127, 137-38.

64. Ely contends as well that the judiciary is institutionally well suited to engage in the enterprise of correcting the sort of political process defects he describes. ELy, supra note 32, at 102-03. This analysis of judicial competence stands alongside two other institutional arguments: Ely asserts that the structure of the Constitution as a whole supports the view that making substantive value choices is a matter remitted in the first instance to the political process, and, second, that a representation-reinforcing approach to judicial review is consistent with democratic values. Id. at 88-102.

65. See generally Peller, supra note 35 .

66. See, e.g., Bruce A. Ackerman, Beyond Carolene Products, 98 HARv. L. Rgv. 713, 737-38 (1985); Paul Brest, The Substance of Process, 42 Oнro Sт. L.J. 131, 131 (1981); Daniel R. Ortiz, Pursuing a Perfect Politics: The Allure and Failure of Process Theory, 77 VA. L. Rev. 721, 722-28 (1991); David A.J. Richards, Moral Philosophy and the Search for Fundamental Values in Constitutional Law, 42 Oнro St. L.J. 319, 331 (1981); Laurence Tribe, The Puzzling Persistence of Process-Based Constitutional Theories, 89 YALE L.J. 1063, 1064 (1980).

67. See supra note 37 and accompanying text. 
participation. Michael Klarman recently has argued that reliance on the theory of paragraph two alone, in the form of vigorous enforcement of minority voting rights, in all likelihood would have secured the goals Ely sought to reach via the "prejudice" prong. ${ }^{68}$ This "third generation" process theory-one that regards judicial review as justified only when deployed to correct formal political process defects-attempts to escape the criticism directed against the third paragraph of Footnote Four. In Klarman's view, a political process theory that relies solely on the "access" prong of Footnote Four "can avoid controversial value choices in identifying appropriate occasions for judicial review . . .."69 Of course, this assertion elicits a critique analogous to that raised in connection with the "prejudice" approach to process defects-it works only if there is some value-neutral way to identify deficiencies in political access. ${ }^{70}$

It should be apparent that the second and third generation process theories combine the two strands of what I have called the process perspective. The point of departure for each theory is the principle of deference to legislative judgment, based on a conception of democracy that prefers majoritarian forms of societal decisionmaking; each then proceeds to find a justification for judicial review in an analysis of institutional competence. Nevertheless, I undertake in Part II to assess separately the impact of each strand of the process perspective: Part II.A focuses on the principle of judicial restraint as it plays out in constitutional doctrine, and Part II.B looks at the doctrinal consequences of the process-theoretical emphasis on analyzing institutionally appropriate decisionmaking procedures.

\section{II}

\section{The Impact of the Process Perspective}

This Part examines the impact of the process perspective on the development of post-Brown constitutional race discrimination law. ${ }^{71}$ It must be conceded at the outset, however, that the Supreme Court has not adopted the processual approach in any overt manner. ${ }^{72}$ Rather, the influence of process considerations has been more subtle, and perhaps more pervasive, than doctrinal analysis would suggest. The process perspective has shaped

68. See Michael J. Klarman, The Puzzling Resistance to Political Process Theory, 77 VA. L. Rev. 747,748 (1991).

69. Id. at 783.

70. See Ortiz, supra note 66 , at $727-29$.

71. A more general argument that process-oriented constitutional theory exerts a conservative influence on constitutional doctrine can be found in Richard B. Saphire, The Search for Legitimacy in Constitutional Theory: What Price Purity?, 42 OHIo ST. LJ. 335 (1981). However, Mark Tushnet has argued that constitutional theory is merely epiphenomenal. See Mark V. Tushnet, Does Constitutional Theory Matter?: A Comment, 65 TEx. L. REv. 777 (1987).

72. Daniel Ortiz has noted that as of 1991 , the Court had cited Democracy and Distrust only ten times, mostly in dissenting or concurring opinions, and that the Court had followed Ely only occasionally, principally in cases not of central interest for processual theory. Ortiz, supra note 66, at 721 n.3. 
the universe of constitutional discourse; it has become the background against which constitutional questions themselves are framed.

My analysis focuses on the two defining landmarks of contemporary race discrimination law: Washington $v$. Davis, ${ }^{73}$ the case in which the Court adopted the rule that a constitutional violation may not be predicated on the existence of racially disparate effects absent proof of discriminatory intent, and City of Richmond v. J.A. Croson Co., ${ }^{74}$ in which a majority of the Court finally settled on strict scrutiny as the standard of review that is to be applied to all instances of race-specific government action. These cases exemplify what many commentators see as the current trend in the Supreme Court's interpretation of the Equal Protection Clause. ${ }^{75}$ If a case can be made that the process perspective has had an impact on these two central doctrinal areas, then even a relatively mild influence is noteworthy.

The argument that the process perspective has had a discernible, albeit diffuse, effect on the constitutional disparate impact and "affirmative action" doctrines is divided along the lines set forth in Part I. In Section A, I examine the impact of the perceived difficulty of justifying judicial review; Section B looks at analyses emphasizing matters of institutional competence. I contend that each of these characteristic themes of the processual stance has affected the Court's approach to the disparate impact problem, and that the latter theme-the focus on processes of decisionmaking-has influenced the "affirmative action" doctrine in an unexpected way. ${ }^{76}$

In addition, I argue that the process perspective's influence on constitutional race discrimination law has been "negative," in the sense that in each doctrinal instance, the processual perspective has exerted pressure in the direction of rules that are in practice less congenial to non-white interests than available alternatives. Section $C$ advances the claim that today's race discrimination doctrine is less apt as a tool for effectuating substantive racial justice than it might have been absent the influence of the process perspective.

73. 426 U.S. 229 (1976).

74. 488 U.S. 469 (1989).

75. In addition, commentators frequently characterize these cases as a regressive move away from the apparent promise of Brown v. Board of Education, 347 U.S. 483 (1954). See Frances L. Ansley, Stirring the Ashes: Race, Class and the Future of Civil Rights Scholarship, 74 CORNell L. Rev. 993, 999-1004 (1989); Kimberle W. Crenshaw, Race, Reform, and Retrenchment: Transformation and Legitimation in Antidiscrimination Law, 101 HARv. L. Rev. 1331, 1346-49 (1988); Alan Freeman, Antidiscrimination Law: The View From 1989, 64 Tul. L. REv. 1407, 1429-33 (1990); David A. Strauss, Discriminatory Intent and the Taming of Brown, 56 U. CHr. L. REv. 935, 951-54 (1989). However, for an argument that Brown's promise was more apparent than real, see Louis M. Seidman, Brown and Miranda, 80 CALIF. L. REv. 673 (1992).

76. I emphasize that I am not claiming that process theory is causally responsible for the adoption of the doetrines under review here. Rather, this analysis attempts to illuminate the covert pressure the process perspective has exerted on emerging race discrimination doctrine. 


\section{A. Justifying Judicial Review}

One of the central legacies of the process perspective is the perception that judicial review requires justification because the judiciary is a "counter-majoritarian" institution. ${ }^{77}$ From this perspective, one begins the constitutional analysis with a presumption of legislative regularity: ${ }^{78}$ some special circumstance is required to validate a stance other than judicial deference to the legislature's judgment. Doctrinally, this "deference-anddeparture" framework finds its expression in the notion of different "levels" of review. Nondeferential judicial review is generally labeled "heightened scrutiny," a term that underscores its status as a departure from the norm.

The effects of the presumption against the legitimacy of judicial review are most pronounced in the area of modern substantive due process. ${ }^{79}$ In virtually every modern substantive due process case, one finds at least one judicial opinion setting forth institutional reasons against recognizing the right at issue. Justice White's opinion for the Court in Bowers v. Hardwick $^{80}$ is paradigmatic:

The Court is most vulnerable and comes nearest to illegitimacy when it deals with judge-made constitutional law having little or no cognizable roots in the language or design of the Constitution. That this is so was painfully demonstrated by the face-off between the executive and the Court in the 1930's, which resulted in the repudiation of much of the substantive gloss that the Court had placed on the Due Process Clauses of the Fifth and Fourteenth Amendments. There should be, therefore, great resistance to expand the substantive reach of those Clauses, particularly if it requires redefining the category of rights deemed to be fundamental. Otherwise, the Judiciary necessarily takes to itself further authority to govern the country without express constitutional authority. ${ }^{81}$

As this passage indicates, the concern over institutional legitimacy exerts a restrictive influence on the scope of substantive due process doctrine. Because judicial intervention is seen as inherently problematic, limiting the number of instances in which it is exercised promises to place the judiciary in a more institutionally appropriate light. Thus, as was the case in Hardwick, arguments against extending constitutional protection to

77. See supra text accompanying notes 27-30.

78. See Thayer, supra note 21 , at 149.

79. "Modern substantive due process" refers to the line of cases that recognizes, or addresses the possible recognition of, a "right of privacy" protected under the due process clauses of the Fifth and Fourtecnth Amendments. The series of modern cases begins with Griswold v. Connecticut, 381 U.S. 479 (1965) (right to contraception), and includes, among others, Roe v. Wade, 410 U.S. 113 (1973) (abortion); Moore v. City of East Cleveland, 431 U.S, 494 (1977) (family); Bowers v. Hardwick, 478 U.S. 186 (1986) (homosexual conduct); and Cruzan v. Director, Mo. Dep't of Health, 497 U.S. 261 (1990) (right to refuse medical treatment).

80. 478 U.S. 186 (1986).

81. Id. at $194-95$. 
"new," unenumerated individual interests typically rest on institutional grounds. ${ }^{82}$

In addition, institutional concerns affect the content of recognized constitutional rights. It can be argued that the counter-majoritarian nature of judicial review is mitigated to the extent that the judiciary implements values that are widely and traditionally shared in our society. Accordingly, it is not uncommon for the Justices to adopt what they perceive to be a tradition-reinforcing interpretation of existing substantive due process rights. Such an approach may be viewed as institutionally appropriate because it serves only to secure, rather than displace, the majority's fundamental value choices. In Michael $H$. v. Gerald $D .{ }^{83}$ for example, Justice Scalia responded to the same institutional concerns reflected in the passage from Hardwick quoted above: "In an attempt to limit and guide interpretation of the [Due Process] Clause, we have insisted not merely that the interest denominated as a 'liberty' be 'fundamental' (a concept that, in isolation, is hard to objectify), but also that it be an interest traditionally protected by our society." 84

There are significant parallels between the reasoning employed in the , substantive due process cases and in the equal protection race discrimination cases; nistitutional concerns also have affected the scope and content of constitutional race discrimination doctrine. For example, one of the principal arguments offered in support of the Washington v. Davis ${ }^{85}$ holding was nistitutional in nature. The Court reasoned:

A rule that a statute designed to serve neutral ends is nevertheless invalid, absent compelling justification, if in practice it benefits or burdens one race more than another would be far reaching and would raise serious questions about, and perhaps invalidate, a whole range of tax, welfare, public service, regulatory, and licensing statutes that may be more burdensome to the poor and to the average black than to the more affluent white. ${ }^{86}$

One reading of this passage understands it to assert that applying strict scrutiny in all disparate impact cases would engage the courts too extensively in overseeing social policy. Such activity arguably would be institutionally inappropriate solely by virtue of the volume of decisions involved; it is not seemly for the Court to appear to have a hand in managing such a

82. See, e.g., Moore, 431 U.S. at 544 (White, J., dissenting); Roe, 410 U.S. at 174 (Rehnquist, J., dissenting); Griswold, 381 U.S. at 513 (Black, J., dissenting).

83. 491 U.S. 110 (1989).

84. Id. at 122 (footnote omitted). Another example can be found in Justice Holmes' dissent in Lochner v. New York, 198 U.S. 45, 76 (1905) (Holmes, J., dissenting):

I think that the word liberty in the Fourteenth Amendment is perverted when it is held to prevent the natural outcome of a dominant opinion, unless it can be said that a rational and fair man necessarily would admit that the statute proposed would infringe fundamental principles as they have been understood by the traditions of our people and our law.

85. 426 U.S. 229 (1976).

86. Id. at 248 . 
wide range of policy choices. From the process perspective, an "effects test" would contravene the principle favoring limited use of the power of judicial review. ${ }^{87}$

Moreover, the institutional concerns embodied in the presumption against judicial review may have exerted an influence on the substantive content of race discrimination law as well. The discriminatory intent requirement adopted in Washington v. Davis diverged from the Court's contemporaneous interpretation of Title VII. In Griggs v. Duke Power Co. ${ }^{88}$ the Court had ruled that a showing of racially disparate effects alone, without proof of discriminatory intent, would be sufficient to support the finding of a Title VII statutory violation absent proof by the defendant that the facially neutral criterion at issue was related to job performance. ${ }^{89}$ The Court of Appeals in Davis had applied the Griggs standard in the constitutional context, ${ }^{90}$ but this approach was rejected by the Supreme Court without meaningful explanation. ${ }^{91}$

87. However, institutional considerations recede for those who hold the view that there is a clear constitutional command prohibiting race-neutral action with racially disparate effects. See, e.g., Charles L. Black, Jr., The Lawfulness of the Segregation Decisions, 69 YALE L.J. 421, 421 (1960) ("[T]he [E]qual [P]rotection [Cllause of the fourteenth amendment should be read as saying that the Negro race, as such, is not to be significantly disadvantaged by the laws of the states."). This "antisubordination" analysis of equal protection is elaborated in TRIBE, supra note 13, at 1514-21 (proposing an interpretation that prohibits treating some people as second-class citizens); Ruth Colker, Anti-Subordination Above All: Sex, Race, and Equal Protection, 61 N.Y.U. L. Rev. 1003 (1986) (interpreting equal protection as disallowing the subordination of certain groups in society); Flagg, supra note 10, at 1014 n.224 (describing the antisubordinationist interpretation of the Fourteenth Amendment); Alan D. Freeman, Legitimizing Racial Discrimination Through Antidiscrimination Law: A Critical Review of Supreme Court Doctrine, 62 MnN. L. Rev. 1049 (1978) (advocating a perspective that focuses on "victims").

Analogously, if one accepts the transparency thesis set forth infra at notes 177-94 and accompanying text, transparency-conscious review could be justified as the implementation of an equal protection principle disfavoring race-speeific government decisionmaking. See Flagg, supra note 10, at 994 n. 140 .

88. 401 U.S. 424 (1971).

89. The Griggs opinion states that "[Title VII] proscribes not only overt discrimination but also practices that are fair in form, but discriminatory in operation. The touchstone is business necessity. If an employment practice which operates to exclude Negroes cannot be shown to be related to job performance, the practice is prohibited." Id. at 431. The Court added, "good intent or absence of discriminatory intent does not redeem employment procedures or testing mechanisms that operate as 'built-in headwinds' for minority groups and are unrelated to measuring job capability." Id. at 432.

There was a period of uncertainty among commentators and within the Supreme Court itself as to whether Griggs really meant what it had appeared to have said: that intent plays no part in a Title VII disparate impact claim. See George Rutherglen, Disparate Impact Under Title VII: An Objective Theory of Discrimination, 73 VA. L. REv. 1297, I298 (1987). The matter was resolved by Congress in the Civil Rights Act of 1991, $\$ 105,42$ U.S.C. $\$ 2000 \mathrm{e}-2(\mathrm{k})(1)(\mathrm{A})$ (Supp. III 1988) (plaintiff need only prove disparate impact on the basis of race, color, religion, sex, or national origin; the burden then shifts to the defendant to prove that the disputed employment practice is job related and consistent with business necessity).

90. Davis v. Washington, 512 F.2d 956, 959 (D.C. Cir. 1975), rev'd sub nom. Washington v. Davis, 426 U.S. 229 (1976).

91. The Court said only: "We have never held that the constitutional standard for adjudicating claims of invidious racial discrimination is identical to the standards applicable under Title VII, and we decline to do so today." Davis, 426 U.S. at 239. 
Unexpressed processual presuppositions may account for the Court's different stance in Title VII and constitutional disparate impact cases. The first step in this analysis is the proposition that the intent requirement reflects a distinctively white manner of thinking about race discrimination. I have argued elsewhere that white people tend to see intent as integral to racial harm in a way that people of color do not; that adopting the intent requirement presupposes the existence of race-neutral decisionmaking, a proposition more attractive to white people than to non-whites; and that retaining the intent requirement in the face of its inadequacy as a means of accomplishing racial justice reflects a complacency concerning the status quo that can only be felt by its beneficiaries-white people. ${ }^{92}$ Assuming these arguments to be persuasive, the requirement of discriminatory intent represents the dominant, and in that sense traditional, way of thinking about race discrimination.

A Court that shared the process perspective on judicial review would be more hesitant to depart from this dominant understanding of discrimination when interpreting the Constitution than when interpreting a statute, because in the latter instance majoritarian correction would be more readily available. ${ }^{93}$ Thus, though the Court apparently did diverge from the prevailing intent-based conception of race discrimination when interpreting Title VII in Griggs, its unwillingness to take the same stance in a constitutional case can be explained by institutional concerns characteristic of the process perspective. Indeed, the Davis opinion contains a suggestion of the institutional rationale: "[П]n our view, extension of the rule beyond those areas where it is already applicable by reason of statute, such as in the field of public employment, should await legislative prescription." ${ }^{94}$ In this way, then, concern over the legitimacy of judicial review seems to have played a role in tailoring the substantive contours of equal protection doctrine to conform to what is "traditional" in our society, just as it has done in the development of substantive due process doctrine. ${ }^{95}$

This parallel between substantive due process and equal protection doctrine may be somewhat unexpected because, from the Court's perspec-

92. See Flagg, supra note 10 , at $968-69$.

93. The suspected bias and hostility that justify heightened judicial review in cascs of explicitly race-conscious decisionmaking apparently are viewed by process theorists as negligible risks in disparate impact cases. Thus the theory does not provide for heightened review upon proof of disparate effects alone in constitutional cases. In the statutory context, the legislation itself is seen to account for the disparate impact rule adopted in Griggs.

94. Davis, 426 U.S. at 248.

95. Indirect support for the proposition that process theory exerts a pull in the direction of traditional values on all constitutional doctrines is provided by Richard Parker's argument that process theory inherently favors the political status quo. See Richard D. Parker, The Past of Constitutional Theory-And Its Future, 42 Oно ST. L.J. 223 (1981). However, it also has been argued, without particular attention to the influence of process theory, that substantive due process is intrinsically more tradition-oriented than the Equal Protection Clause. See Cass R. Sunstein, Sexual Orientation and the Constitution: A Note on the Relationship Between Due Process and Equal Protection, 55 U. CH. L. REv. 1161, 1163 (1988). 
tive, the problem of legitimacy is less pressing when judicial review is predicated on an explicit constitutional text. ${ }^{96}$ Accordingly, one might have thought that the race discrimination cases would be relatively insulated from processual anxiety over judicial review, because they rest on a textual foundation that is not present in the context of substantive due process analysis. However, process theorists, as well as the Court, have tended to regard the Equal Protection Clause as one of the Constitution's "openended" provisions. ${ }^{97}$ That assessment significantly strengthens the analogy between substantive due process and equal protection; from the process perspective, similar institutional concerns apply to both doctrinal lines.

It might be argued, with some persuasive force, that the vision of institutional roles embodied in the principle of judicial restraint is not causally responsible ${ }^{98}$ for the Court's adoption of the constitutional requirement of discriminatory intent, but is selectively employed as a post hoc rationale for outcomes determined by other factors. ${ }^{99}$ Certainly there is ample reason to understand racism as a phenomenon having a life of its own, and I do not mean to suggest that setting aside the institutional concerns under consideration in this Article would guarantee the adoption of more racially equitable constitutional doctrines. The contention here is just that this facet of the process perspective has facilitated acceptance of the discriminatory intent requirement, and in that way has contributed to the doctrine's retreat from the promise of Brown. ${ }^{100}$

The view that nondeferential judicial review requires justification affects race discrimination doctrine in one additional way. If the legislature is presumptively the institution best suited to make policy judgments, then judicial review, when exercised, arguably should focus on legislative means rather than ends. Means analysis holds out the promise of "value-free" constitutional adjudication, ${ }^{101}$ and so ostensibly would circumvent the counter-majoritarian difficulty. ${ }^{102}$ In short, the first strand of the process perspective pulls in the direction of the second.

96. See supra text accompanying note 81 .

97. See ELY, supra note 32, at 30-32; Klarman, supra note 68, at 769.

98. See supra note 76 .

99. See David Chang, Discriminatory Impact, Affirmative Action, and Innocent Victims: Judicial Conservatism or Conservative Justices? 91 Colum. L. Rev. 790 (1991) (describing the Court's intermittent adherence to the principle of judicial restraint).

100. See supra note 75. For commentary critical of the Court's preoccupation with the problem of judicial review in the context of equal protection analysis, see Kenneth L. Karst, The Supreme Court, 1976 Term-Foreword: Equal Citizenship Under the Fourteenth Amendment, 91 HARv. L. Rev. 1, 3-4 (1977); Kenneth L. Karst \& Harold W. Horowitz, The Bakke Opinions and Equal Protection Doctrine, 14 Harv. C.R.-C.L. L. REv. 7, $21-24$ (1979).

101. See GUNTHER, supra note 16 , at 607 .

102. Constitutional law casebooks illustrate yet another facet of the impact of the process perspective-its influence on the way equal protection problems are framed. There are two models of presentation. The first presents equal protection as an abstract, generic problem having no particular intellectual connection to issues of race. For example, Gunther's chapter on equal protection begins this way: 


\section{B. Evaluating Institutional Decisionmaking Processes}

The animating principle of process jurisprudence is the proposition that evaluation of institutionally appropriate decisionmaking procedures can be undertaken without regard to matters of substance. ${ }^{103}$ If it is correct to conclude that process and substance can be separated in this manner, one would expect that focusing one's attention on processual concerns would not affect the substantive content of one's constitutional analyses. That expectation, however, has not been borne out in practice.

This Section examines the way process-oriented approaches operate to privilege some substantive positions over others. First, I describe the way in which process theorists' attention to processes of legislative decision-

We now turn to the range of complex problems raised by the simple-sounding command of the 14th Amendment that no state shall "deny to any person within its jurisdiction the equal protection of the laws." Presumably, that command cannot mean that all laws must deal in the same way with everyone. Almost all laws classify (or "discriminate") by imposing special burdens or granting special benefits to some people and not to others. But if legislation almost in its nature classifies, what content can be given to the equal protection guarantee?

GUNTHER, supra note 16, at 601 (parenthetical in original).

Other casebooks treat race discrimination as a distinct substantive issue. The Redlich, Schwartz, \& Attanasio casebook provides an example of this approach:

While there has been considerable debate over the intended scope of the Thirteenth, Fourteenth and Fiftecnth Amendments, there is no doubt that a dominant force behind the Amendments was the desire to secure equal rights for the newly-freed slaves. The Thirteenth and Fifteenth Amendments directly address slavery and racial equality. The Fourteenth Amendment, while far broader in its language and in its subsequent interpretation, emerged in large part from doubts about congressional power to protect individuals against state violation of civil rights-particularly those infringements which were based on race or which constituted the perpetuation of slavery. As the legacy of slavery remains, questions of racial equality will continue to shape the interpretation of the great Amendments which enshrined in law the military result of the Civil War.

Norman Redich et al., Constmutional Law 565 (2d ed. 1989).

At this writing, seven of eleven currently available casebooks follow the first, processual presentation. See Jerome A. Barron et al., Constitutional law: Principles and Policy (4th cd. 1992); Paul Brest \& Sanford Levinson, Processes of Constitutional Decisionmakina: Cases and Materials (3d ed. 1992); Wullam Cohen \& Jonathan D. Varat, Constitutional law: Cases and Materials (9th ed. 1993); David Crump et al., Cases and Materials on Constitutional Law (1989); Gunther, supra; William B. Lockhart et al., Constitutional Riohts and Liberties: Cases-Comments-Questions (7th ed. 1991); Ronald D. Rotunda, Modern Constitutional LAw: CASES AND Notes (4th ed. 1993). Moreover, the three books that follow the second, "substantive" model are relatively new arrivals on the market. See Daniel A. FARBer Et AL., CASES and Materials on Constitutional Law: Themes for the Constitution's Third Century (1993); ReDLICH ET AL., supra (first edition published 1983); GeOFFreY R. STONE ET AL., ConstrTUtional LAW (2d ed. 1991) (first edition published 1986). Before 1983, then, the processual model occupied the field, and it continues to enjoy a substantial advantage in the number of students exposed to it.

One current casebook conforms to neither model of presentation; it intermingles substantive due process and equal protection cases. See DaAn Braveman \& William C. Banks, Constitutional Law: Structure and Rights in Our Federal. System (2d ed. 1991).

103. For example, Wechsler criticized the reasoning in the Brown opinion while approving the result. See Wechsler, supra note 42, at 27 ("I still believe that the decisions I have mentioned-dealing with the primary, the covenant, and schools-have the best chance of making an enduring contrihution to the quality of our society of any that I know in recent years."); see also Derrick A. Bell, Jr., Brown v. Board of Education and the Interest-Convergence Dilemma, 93 HARV. L. REv. 518, 519-21 (1980) (noting that Wechsler began his Holmes lectures by saying he welcomed the result in Brown). 
making helped pave the way for the Washington $v$. Davis ${ }^{104}$ requirement of discriminatory intent. Second, I argue that the institutional orientation militates in favor of a particular substantive interpretation of equal protectionthe "colorblindness" conception of equality. That stance finds expression in the doctrinal requirement of discriminatory intent in disparate impact cases and the City of Richmond v. J.A. Croson Co. ${ }^{105}$ rule mandating strict scrutiny of all race-specific government action. This latter point-that processual concerns pull in a direction consistent with the current "affirmative action" doctrine - may be especially unexpected in view of the fact that second-generation process theory contends, on its face, for a different doctrinal outcome: one that calls for a less interventionist standard of review in cases in which a majority acts to disadvantage itself politically.

In principle, the Washington $v$. Davis rule presupposes that reviewing courts are able to make meaningful inquiries into legislative motive in order to discern the presence of discriminatory intent. ${ }^{106}$ "Motive review" is a task that the Supreme Court itself at times has characterized as either difficult or inappropriate. In United States v. $O^{\prime}$ Brien, ${ }^{107}$ the Court identified three problems intrinsic to the inquiry into legislative motive: ascertainability, futility, and disutility. ${ }^{108}$ "Ascertainability" refers to the inherent difficulty of determining what motivates legislators to vote for a given measure. ${ }^{109}$ The "futility" criticism alludes to the fact that a law declared invalid because of impermissible purposes subsequently may be reenacted, this tinie with a declaration of more acceptable goals. ${ }^{110}$ "Disutility" denotes the reality that invalidation on the ground of "bias" or "hostility" might disable legislation that was in fact beneficial in its overall effect. ${ }^{111}$ Taken together, these objections appeared to the Court to present a very powerful argument against motive review.

Ascertainability, futility, and disutility are just the sort of institutional difficulties that process theory characteristically finds problematic; thus, one might expect process theorists to oppose judicial review of legislative

104. 426 U.S. 229 (1976).

105. 488 U.S. 469 (1989).

106. In practice, the Court may be less sanguine about this enterprise. In general, claims of discriminatory intent apparently may be defeated by the existence of any nondiscriminatory explanation for a challenged action. See Daniel R. Ortiz, The Myth of Intent in Equal Protection, 41 StAN. L. REv. 1105, 1115-16 (1989). However, Ortiz notes that informal rules regarding proof of discriminatory intent may vary with the interest at stake. Id. at 1140-41.

107. 391 U.S. 367 (1968). The legislative motive question in O'Brien was whether a law prohibiting destruction of draft cards was enacted for the purpose of suppressing speech. Id. at 382-86.

108. These three objections to judicial review of legislative motive acquired these labels in the scholarly literature on the subject. See, e.g., John Hart Ely, Legislative and Administrative Motivation in Constitutional Law, 79 YALE L.J. 1205, 1212-17 (1970). See generally Symposium, Legislative Motivation, 15 SAN Diego L. Rev. 925 (1978).

109. Ely, supra note 108 , at 1212-14.

110. Id. at 1214-15.

111. Id. at 1215-17. 
motives. ${ }^{112}$ However, some process theorists were instrumental in making the case for the propriety of motive review. ${ }^{113}$ They argued that the need for, and benefits of, motive review outweigh the institutional difficulties just described. Without motive review, they claimed, legislation that should be regarded as unconstitutional because it had been influenced by clearly impermissible purposes would evade judicial scrutiny. ${ }^{114}$

At the doctrinal level, process theorists' support for the propriety of motive review may have helped to make possible the Court's conclusion in Washington $v$. Davis that the relevant inquiry concerned a legislature's intent in enacting a statute, rather than the statute's effect. In 1960, the Supreme Court had expressed approval of motive review: "Acts generally lawful may become unlawful when done to accomplish an unlawful end ...."115 However, subsequent opinions cast doubt on the Court's commitment to motive review, and in 1968 the Justices appeared to reverse course in O'Brien: "The decisions of this court from the beginning lend no support whatever to the assumption that the judiciary may restrain the exercise of lawful power on the assumption that a wrongful purpose or motive has caused the power to be exerted."116 The Court reiterated its disapproval of motive review in a 1971 race discrimination case, Palmer $v$. Thompson, ${ }^{117}$ which ruled that a decision to close segregated public swimming pools rather than integrate them could not be deemed a violation of equal protection "solely because of the motivations of the men who voted for it."118 That holding convinced many federal courts of appeal that legislative motive was to be regarded as irrelevant to constitutional analysis. ${ }^{119}$

In the early 1970s, John H. Ely and Paul Brest published influential articles arguing that motive review was institutionally appropriate. ${ }^{120}$ It would be too much to conclude that these commentaries directly influenced the Davis Court, because the Davis opinion includes no discussion of Ely's

112. See Wechsler, supra note 42 , at 33 (noting that inquiries into motive of legislature are "generally foreclosed to the courts").

113. See, e.g., Ely, supra note 108, at 1222-23 ('There are, nonetheless, substantial areas of constitutional adjudication where recourse to the motivation of legislators . . . is entirely proper . . .."); Paul Brest, Palmer v. Thompson: An Approach to the Problem of Unconstitutional Legislative Motive, 1971 SUP. CT. REv. 95, 115-18 (articulating the case for judicial review). Ely reiterated and expanded the arguments in Democracy and Distrust. ELY, supra note 32, at 136-45.

114. In other words, motive review allows courts to supervise prejudice-related process defects. See ELY, supra note 32 , at 136-45.

115. Gomillion v. Lightfoot, 364 U.S. 339, 347 (1960) (quoting Western Union Tel. Co. v. Foster, 247 U.S. 105, 114 (1918)). In Gomillion, no factor other than discriminatory intent could explain the redistricting of Tuskegee, Alabama: after boundary lines had been redrawn, nearly all black voters found themselves outside the new city limits. Id. at 341 .

116. 391 U.S. at 383 (quoting McCray v. United States, 195 U.S. 27, 56 (1904)).

117. 403 U.S. 217 (1971).

118. Id. at 224.

119. Many of these appellate decisions were cited by the Supreme Court in Washington v. Davis, 426 U.S. 229, 244 n.12.

120. See Brest, supra note 113; Ely, supra note 108. 
or Brest's articles, nor any mention of the institutional factors that counsel against motive review. However, because of the attention that had been paid to motive review, and the indecision surrounding the problem in previous cases, ${ }^{121}$ the Court's abrupt resolution of the issue in Davis strongly suggests that something had changed; the only plausible candidate is the appearance of process-based arguments in favor of motive review. At a minimum, the process-theoretical perspective must have contributed to lowering a significant barrier to adoption of the discriminatory intent requirement.

Viewed from another angle, the question whether proof of racially discriminatory purpose should be required in constitutional disparate impact cases presented competing institutional concerns. On the one hand, motive review seemed institutionally unwieldy because of the ascertainability, futility, and disutility problems; but on the other hand, engaging in heightened scrutiny in all disparate effects cases carried significant institutional problems as well. ${ }^{122}$ At the time this doctrinal issue was percolating up through the lower courts, the Supreme Court had been wrestling with the first of these considerations, but the second was not presented until the arrival of Washington v. Davis itself. Once confronted with the conflict between these two institutional difficulties, it might be contended, the Court saw the problems posed by the extent of review that would be necessary if disparate impact alone triggered heightened scrutiny as more prohibitive than the difficulties presented by engaging in motive review, and so opted for motive review and the requirement of discriminatory intent. In this framework, I suggest that the process theorists' assessment that motive review was institutionally permissible helped the Court strike the balance in the way that it did. ${ }^{123}$ Absent the guidance of these commentators on the problem of motive review, the Court might have found it more difficult to impose an intent requirement in constitutional race discrimination cases. ${ }^{124}$

Moreover, the impact of the process-theoretical approach on the substantive content of race discrimination doctrine has been more pervasive than a narrow focus on the problem of motive review might suggest. The process perspective systematically favors one particular substantive position-the colorblindness conception of equality-over available alternatives.

121. Ely described the problem as having reached "disaster proportions." Ely, supra note 108, at 1207.

122. See supra text accompanying notes 85-87.

123. It should be noted as well that in the 1970 s no process theorist pressed the institutional arguments against motive review.

124. In addition, regulating "inputs" to legislative decisionmaking promised freedom from substantive judicial review. See Ortiz, supra note 106, at 1008-10. Ortiz argues, however, that this promise has not been fulfilled. Id. at 1134-42. 
In general, colorblindness is the principle that race should not be taken into account in assessing the individual; ${ }^{125}$ viewed as an interpretation of the Equal Protection Clause, it is the proposition that government behaves consistently with that constitutional command when it acts without regard to race. ${ }^{126}$ In contrast, the antisubordination principle contends that certain groups should not occupy socially, culturally, or materially subordinate positions in society. ${ }^{127}$ Accordingly, under this conception of equality, government action would be held constitutionally acceptable only to the extent that it did not create, reinforce, or perpetuate those groups' subordinate status. ${ }^{128}$

Colorblindness is the dominant principle in constitutional doctrine today, and is embodied in both the discriminatory intent requirement and the "strict scrutiny" rnle for government "affirmative action." 129 The reasons colorblindness has attained its seemingly unassailable position undoubtedly are complex, ${ }^{130}$ but it is evident that the end result is a form of transparency. ${ }^{131}$ That is, colorblindness has come to be conceived by white people as a "neutral" view, one that does not require moral justification. ${ }^{132}$

125. This principle has been given other labels as well: "the antidiscrimination principle"; "formalrace"; "colorblind meritocratic fundamentalism"; "integrationism." For a comprehensive discussion of colorblindness in the context of constitutional law, see Neil Gotanda, A Critique of "Our Constitution Is Color-Blind," 44 STAN. L. REv. 1 (1991). The history of colorblindness as constitutional doctrine is traced in ANDrew Kull, The Color-Blind Constitution (1992).

126. Existing constitutional rules proseribe only race-conscious action; they do not reach unconscious discrimination. See Flagg, supra note 10, at 980 . However, for an argument to the contrary, see Strauss, supra note 75, at 956-62.

127. The groups in question are those defined by race, gender, physical or mental disability, etc. Such characteristics have in common the fact that they carry cultural significance relevant to social status. For more complete descriptions of the antisubordination principle, see sources cited supra note 87.

128. Antisubordination analysis is indifferent to the presence or absence of race-specificity. Indeed, in some instances the constitutional command not to perpetuate racial subordination might mandate affirmative government measures. See David A. Strauss, The Myth of Colorblindness, 1986 Sup. CT. Rev. 99, 130-32.

129. See Strauss, supra note 75, at 953-54 (arguing that Davis read the Equal Protection Clause to prohibit only explicit classifications and facially neutral race-based actions).

130. Gary Peller's thesis provides one explanation: "the contemporary mainstream image of racial justice in terms of transcending race consciousness was embraced in part to resolve the particular 'threat' that black nationalism represented in the late 1960s and early 1970s . . ." Gary Peller, Race Consciousness, 1990 DUKE L.J. 758, 763. Another argument suggests that in principle and in practice the colorblindness principle serves white interests. See Derrick BeLl, AND WE ARE Not SAved 129. 30 (1987); Ansley, supra note 75, at 1000, 1010-23; Thomas Ross, Innocence and Affirmative Action, 43 VAND. L. REv. 297 (1990).

131. "Transparency" refers to the fact that white people rarely take conscious note of whitcness. See infra text accompanying note 177-93.

132. For example, in Croson Justice Scalia asserted that "discrimination on the basis of race is illegal, immoral, unconstitutional, inherently wrong, and destructive of democratic society." City of Richmond v. J.A. Croson Co., 488 U.S. 469, 521 (1989) (Scalia, J., concurring) (quoting AleXANDER M. BiCKel, The Morality of Consent 133 (1975)). As I read it, there are three claims here; that colorblindness is an established constitutional principle, that it is morally self-evident, and that it is necessary for the attainment of a racialiy just society. The first of these contentions is factually incorrect, see Flagg, supra note 10, at 1006-08, and the third is debatable, see id. at 1013-14. I believe 
My contention is that the process perspective has had a hand in the ascension and "neutralization" of colorblindness as a constitutional principle. Both Wechsler's and Ely's versions of process theory privilege the colorblimdness conception of equality in practice, and simultaneously provide it a degree of protective cover.

Wechsler's discussion of Brown implies that a decision resting on an explicit colorblindness rationale would satisfy his "neutral principles" standard for evaluating judicial decisionmaking, but that one relying on an antisubordination rationale would not. The basic components of Wechsler's neutrality requirement seem to be uniformity of application (judicial decisions ought not to rest on principles that one would not apply in other, relevantly similar contexts) and adequate generality (a "neutral principle" is one that is articulated broadly enough that its scope of application is reasonably clear). ${ }^{133}$ Wechsler noted that the Court did not articulate a colorblindness rationale in Brown. ${ }^{134}$ One might suppose that had he thought colorblindness an adequate, "principled" basis for the decision, he would have said so, but he did not pursue that line of argument in Neutral Principles. ${ }^{135}$ However, it does not follow that Wechsler discerned an inherent flaw in the colorblindness approach. There is one additional clue: he later commented that

[w] hether the Fourteenth Amendment should be read to outlaw race or color as determinants of all official action must be tested not alone by the effect of such a principle on state-required segregation but also by its impact upon measures that take race into account to equalize job opportunity or to reduce de facto segregation, as in New York City's schools. ${ }^{136}$

the moral point is central for Justice Scalia; it was echoed in Croson by Justice Kennedy: "The moral imperative of racial neutrality is the driving force of the Equal Protection Clause." Croson, 488 U.S. at 518 (Kennedy, J., concurring). The moral status of the colorblindness principle of course is contestable. See Flagg, supra note 10, at 1010-13.

133. This account of Wechsler's position follows the analysis set forth by Kent Grecnawalt, supra note 44 , at $985-90$. Greenawalt mentions three additional elements of the neutrality principle: a decision must rest on principles of law, it must follow the neutrality requirement with respect to every step in a decision, and the judge's opinion must refiect the reasoning actually employed. Id.

134. Wechsler, supra note 42 , at 32 ("The Court did not declare . . that the fourteenth amendment [sic] forbids all racial lines in legislation ...."). Wechsler discussed a possible freedom of association rationale for Brown in addition to the equality principles examined here. See id. at 34 .

135. He did suggest that the subsequent per curiam decisions regarding segregated public facilities might establish colorblindness as the prevailing interpretation of equal protection. See id. at 32. The argument that those decisions supported a colorblindness interpretation of Brown is explicated in Andreas Auer, Public School Desegregation and the Color-Blind Constitution, 27 Sw. L.J. 454, 458-59 (1973). For Wechsler, of course, the per curiam decisions violated the requirement that judicial reasoning be fully articulated. Wechsler, supra note 42, at 22-23.

136. WECHSLER, supra note 44 , at xiv. 
I read this passage to imply that a colorblindness doctrine would satisfy the "neutrality" requirement if one were willing to apply it absolutely, across the board. ${ }^{137}$

Wechsler read the Brown decision as resting on the judgment that segregation was "inherently unequal" because of its "deleterious effects upon the colored children in implying their inferiority, effects which retard their educational and mental development."138 In Wechsler's view, this ground of decision was problematic because it either involved motive reviewimpermissible in these circumstances-or made "the measure of validity of legislation the way it is interpreted by those who are affected by it[.]"139 However, it is not entirely clear why a rule that had reference to experiences of stigmatic harm would be inconsistent with the "neutrality" requirement. ${ }^{140}$ Wechsler's examples suggest that he had in mind the difficulty that there are always multiple perceptions of a single event, and often no principled way to choose between them. ${ }^{141}$ One wonders, then, whether a formulation that substituted a normative notion of harm or disadvantage for the perceptions of individuals would be satisfactory. Wechsler indicated that Charles Black's proposal - that Brown be read to rest on the principle that "the Negro race, as such, is not to be significantly disadvantaged by the laws of the states"142 — would not allay his concerns. ${ }^{143} \mathrm{I}$ believe Wechsler found Black's antisubordinationist approach unacceptable because it made analytic outcomes turn on the identity of affected individuals. ${ }^{144}$

If this reading of Wechsler's views is correct, then a Court that adhered to the "neutral principles" standard could not have adopted any antisubordination interpretation of the Equal Protection Clause. By defini-

137. I see no other way in which a prohibition against race-specific action would violate Wechsler's neutrality requirements. However, Wechsler indicated that he did not find satisfactory the colorblindness explanation of Brown set forth by Louis Pollak, supra note 44. WECHSLER, supra note 44, at xiv-xv. An explanation can be found in the fact that then-Professor Pollak proposed a rule that would subject race-specific action to strict scrutiny, rather than proscribe it outright. Pollak, supra note 44, at 27. The strict scrutiny approach entails a degree of balancing that would be problematic when held up against the generality aspect of Wechsler's approach. See Greenawalt, supra note 44, at 987-89.

I38. Wechsler, supra note 42 , at 32 . Wechsler rejected the cogency of a factual foundation for the assessment of harm; he read the Court as taking the view that segregated education was unequal in principle. Id. at $32-33$.

139. Id. at 33.

140. For example, consider a rule that government action should be deemed to send an impermissible message of endorsement of religion if the activity is perceived by "minorities and nonadherents" to send such a message. See Developments in the Law-Religion and the State, 100 HaRv. L. Rev. 1606, I648 (1987).

141. Wechsler's examples include perceptions of stigmatic harm by blacks, by women, and by "the colored member of [a] couple who would like to marry." Wechsler, supra note 42, at 33-34.

142. Black, supra note 87 , at 421.

143. WECHSLER, supra note 44 , at xiv-xv.

144. This point is closely related to Wechsler's expressed concern over some theorists' and judges' apparent willingness to employ different rules of decision, depending on what groups' interests were at stake. Wechsler, supra note 42, at 12-15. Cass Sunstein reads Wechsler similarly. See Sunstein, supra note 20 , at 895 n.111. 
tion, any analysis that refers to the actual social status of groups would produce outcomes that vary across group lines. However, the Court could opt for the colorblindness conception of equality, if it applied the principle uniformly and without exception. In this sense, Wechsler's approach inherently favors a colorblindness principle of equality.

Colorblindness is privileged in an analogous manner by "second generation" process theory. ${ }^{145}$ Beginning in the 1970 s, political process theorists argued that a colorblindness doctrine could be justified on the ground that race-specific decisionmaking likely reflected process defects. ${ }^{146}$ In this view, race-conscious measures tend to be the product of "hostility" and "selective indifference"--defects that are the targets of the third paragraph of Carolene Products' Footnote Four. ${ }^{147}$ Accordingly, a colorblindness rule that subjects race-specific measures to heightened judicial scrutiny is thought to vindicate "representation reinforcing" values, because it mandates judicial intervention in circumstances that are seen to pose a particular risk of having arisen as a consequence of a defective political process.

However, one could not construct a parallel process defects foundation for an antisubordination doctrine. Under that doctrine, heightened scrutiny would be in order whenever government action operates to create, reinforce, or perpetuate racial subordination, regardless of the cause or motivation behind that subordinating effect. Such an outcome-sensitive rule could not be adopted or justified as a means of ferreting out defective processes of decisionmaking.

While each of these two versions of process theory thus incorporates an indirect preference for one substantive interpretation of equality, they simultaneously provide it an aura of "neutrality." The label attached to Wechsler's analysis carries the point: colorblindness is a "neutral principle," but antisubordination is not. Along the same lines, judicial review triggered by race-specific decisionmaking can be defended on an ostensibly value-neutral process defects theory, but a rule treating societal subordination as the occasion for heightened review cannot. The substantive colorblindness principle thus is afforded some degree of the value-neutrality associated with processual analyses.

The requirement of discriminatory intent in disparate impact cases is, of course, a doctrinal manifestation of the colorblindness principle. ${ }^{148}$ In

145. Because the present argument addresses only the "prejudice" prong of the political process approach, it doesn't apply to Michael Klarman's "third generation" theory. For Klarman's argument that his approach might vindicate values of racial equality and yet avoid the sort of substantive commitments that are at issue here, see Klarman, supra note 68, at 782-819.

146. See Ely, supra note 32, at 147-48; Paul Brest, The Supreme Court, 1975 Term-Foreword: In Defense of the Antidiscrimination Principle, 90 HARV. L. REv. 1, 6-8 (1976).

147. See supra notes $50,60-63$ and accompanying text.

148. Given that the Court intends the discriminatory intent requirement to be a comprehensive rule for constitutional disparate impact cases, it embodies the colorblindness principle, because it mandates that only race-conscious government action will be subject to strict scrutiny. 
addition, the intent requirement is consistent with a process-oriented approach to constitutional interpretation, because it purports to regulate inputs to processes of government decisionmaking, rather than outcomes. ${ }^{149}$ In short, the process perspective and the colorblindness rule converge with regard to the manner in which disparate impact cases are to be adjudged; both militate in favor of the requirement of discriminatory intent.

However, the situation is considerably more complex with respect to the "affirmative action" rule. A claim that process theory has contributed to the strict scrutiny rule of City of Richmond v. J.A. Croson Co. ${ }^{150}$ initially may seem implausible. Political process theorists generally have taken the view that governmental race-conscious "affirmative action" should not trigger heightened judicial review because it is not likely to be the product of a flawed legislative process. ${ }^{151}$ By definition, "affirmative action" disadvantages members of the political majority, and so does not raise suspicions regarding process defects. ${ }^{152}$ Therefore, process theory would afford racespecific action that benefits minorities a greater degree of judicial deference than is given race-specific action that burdens those groups. ${ }^{153}$

Nevertheless, the overtly process-theoretical analysis of the problem of "affirmative action" has given way to the strict colorblindness principle of Croson. One has to wonder why that is so, given the otherwise pervasive influence of the process perspective on constitutional law. ${ }^{154}$ It cannot be denied that factors such as an unconscious desire to maintain a status quo defined and structured by white privilege are important, and perhaps dispositive, but I believe that process theory has had a hand in the evolution of race discrimination doctrine here as well. ${ }^{155}$ Process theory seems inelucta-

149. See Ortiz, supra note 106 , at 1108-10.

150. 488 U.S. 469 (1989).

151. See, e.g., ELY, supra note 32, at 170-72 (arguing that there is no danger that a white majority would use race-based classifications to discriminate against all whites); Klarman, supra note 68, at 82223 (characterizing this country's racial history as one of minority oppression, not minority preferences).

152. But note that the process analysis was misapplied by Justice O'Connor in Croson. 488 U.S. at 495-96. When a group that historically has been the target of racial oppression achieves control of a legislative body, as was the case in Richmond, it is not necessarily a "majority" for the purpose of political process analysis. On the problems of protecting "majorities" as well as "minorities," see Parker, supra note 95, at 239-46; Richard A. Posner, Democracy and Distrust Revisited, 77 VA. L. REv. $641,646-48$ (1991).

153. This process-based position was advanced by the state in Regents of the Univ. of Cal. v. Bakke, 438 U.S. 265 (1978), but it was rejected by Justice Powell, who provided the decisive vote in that case. Id. at 290-91 (Powell, J., plurality opinion).

154. See Michael Klarman, An Interpretive History of Modern Equal Protection, 90 Mich. L. Rev. $213,310-14$ (1991). In addition, strict scrutiny of pro-minority race-specific action is inconsistent with the philosophy of judicial restraint. See Chang, supra note 99, at 793 (arguing that a true judicial conservative would apply an intent requirement to "affirmative action" as well as disparate impact cases); Klarman, supra, at 315 (arguing that colorblindness approach is inconsistent with jurisprudence of original intent); Laurence H. Tribe, "In What Vision of the Constitution Must the Law Be Colorblind?", 20 J. MarshaLl L. Rev. 201, 206-07 (1986) (in all other areas, the "race neutralists" look to the framers' intent, disapprove judicial "improvisation," advocate deference to political majorities, and are reluctant to fashion new rights).

155. See supra note 76 . 
bly drawn to the colorblindness principle. My contention is that this processual endorsement of colorblindness has lent it an aura of neutrality and institutional respectability that has contributed to the Justices' acceptance of colorblindness as an unproblematic stance in constitutional interpretation. The next logical question, however, is whether the effect of the process-theoretical perspective in this regard has been at all sigmificant.

I concede that it is impossible to assess precisely the extent to whicl process theory's partial endorsement has contributed to the "neutralization" of colorblindness. ${ }^{156}$ However, the alternative to the thesis set forth herethat it has had some effect-is to suppose that process theory has had no impact in this area at all; that the Justices would have been equally likely as they are at present to consider colorblindness a self-evident principle of equality had it been presented to them as a contingent and contestable substantive interpretation of the equality guarantee. Given the considerable attraction ostensibly value-neutral modes of reasoning seem to hold for the Court, ${ }^{157}$ it is implausible to imagine that the existence of a process-based defense of colorblindness did not ease the road to its judicial acceptance. ${ }^{158}$

At iminimum, the analysis set forth here should establish that process theory is in a sense at odds with itself with respect to "affirmative action." Even a limited endorsement of across-the-board judicial review of race-specific government decisionmaking (via support for the colorblindness principle) necessarily dilutes process theory's avowed opposition to heightened scrutiny of actions in which the majority disadvantages itself. From this perspective, process theory may be seen as sinultaneously asserting contradictory principles. ${ }^{159}$ To that extent, process theory offers a less effective

156. There is no language in the Supreme Court opinions that points in the direction of the political process rationale for a colorblindness rule. However, the absence of such evidence should not be seen as particularly meaningful, because its presence would signal awareness that colorblindness is not in fact a "neutral" principle.

157. See Ortiz, supra note 106, at 1115-16 (arguing that the Court escapes evaluating the actual policy-worthiness of a decision by reformulating the question from whether decisionmakers would to whether they could make the same decision without discriminatory motive). I discuss two additional areas of constitutional law in which the Justices seen extremely reluctant to engage in substantive constitutional analysis in Barbara J. Flagg, The Algebra of Pluralism: Subjective Experience as a Constitutional Variable, 47 VAND. L. REv. 273, 287-312, 321-23 (1994).

158. The argument set forth here, that process theory has operated in part to advantage a particular substantive constitutional view (i.e., colorblindness), represents a specific instance of the general claim that process theory cannot avoid normative commitments. My present interest is in the specific- the precise substantive position that has been helped to attain a privileged position through the medium of the process approach. The colorblindness interpretation of the Constitution's guarantee of racial equality might be defensible on its own merits, but the case for it is not obvious, and its contingency certainly has not been adequately acknowledged by the judiciary. Because its way into the constitutional debate has been eased by process theory, colorblindness has acquired credentials of "neutrality" it otherwise likely would not have had.

159. They are, respectively, that race-speeific decisionmaking ought to trigger heightened judicial scrutiny because it is likely the product of bias or hostility; and that race-specific decisionmaking that disadvantages members of the deeision-making majority ought not to trigger such heightened scrutiny because there is no risk of bias or prejudice in that case. The two become incompatible with the addition of the proposition that the application of the equality guarantee cannot vary from one individual to 
argument against the Croson rule than it would have had it avoided underwriting the colorblindness principle.

\section{The Negative Effects of Process}

I have argued that process theory has had a multifaceted influence on the development of contemporary constitutional race discrimination law. In the case of the "affirmative action" strict scrutiny rule, perhaps the covert substantive impact of the process perspective has been ameliorated by the fact that process theory overtly calls for judicial deference to legislative judgment when race-specific action benefits minority groups. ${ }^{160}$ Nevertheless, the argument could be made as well that the theory's covert effects have undermined the potential influence of its overt recommendation. With respect to the disparate impact rule, the process perspective has exerted a strong substantive push in the direction of the requirement of discriminatory intent. In addition, it is remarkable that process theorists found their way to a position on the problem of motive review that effectively neutralizes a potential institutional argument against the discriminatory intent rule.

In each of the doctrinal areas under consideration here, the process perspective has had an influence that runs counter to the interests of racial justice. ${ }^{161}$ I describe these doctrines as antithetical to the cause of racial justice because they militate against improving the material situation of blacks and other people of color. ${ }^{162}$ The discriminatory intent requirement places a substantial obstacle in the path of race discrimination plaintiffs who typically have no "smoking gun" evidence of hostile intent. This is especially so in light of the Court's later gloss that "discriminatory purpose" means that a decisionmaker chose a course of action "because of,' not merely 'in spite of,' its adverse effects upon an identifiable group."163 In practice, the Court appears willing to find discriminatory intent only when there is no racially neutral explanation for the challenged action. ${ }^{164}$

another. "The guarantee of equal protection cannot mean one thing when applied to one individual and something else when applied to a person of another color." Regents of the Univ. of Cal. v. Bakkc, 438 U.S. 265, 289-90 (1978) (Powell, J., plurality opinion).

160. I speak here of second-generation process theory. See supra text accompanying notes 51-67.

161. This influence may not be surprising, given the inherently conservative nature of the process approach. See Parker, supra note 95, at 226, 240 (describing process theory's assumption that the processes of our representative democracy are basically in "good order").

162. See Alex M. Johnson, Jr., Defending the Use of Quotas in Affirmative Action: Attacking Racism in the Nineties, 1992 U. ILL. L. REv. 1043, 1049; see also sources cited supra note 75.

In general, I focus on blacks as the group most centrally affected by white supremacy. However, I intermittently refer instead to "non-whites" or "people of color," to indicate that some aspects of the analysis, especially in relation to the transparency phenomenon, apply in similar ways to all non-whites.

163. Personnel Adm'r v. Feeney, 442 U.S. 256, 279 (1979).

164. Though the Court sometimes asserts that discriminatory intent can be inferred from the existence of racially disparate effects, as it did in Washington v. Davis, 426 U.S. 229, 242 (1976), in practice it has taken something like the facts of Gomillion v. Lightfoot, 364 U.S. 339 (1960), to makc the case. In Gomillion the city boundaries were redrawn to form "an uncouth twenty-cight-sided figure." Id. at 340 . Beeause no other explanation for the boundaries was possible, the Court concluded 
Researchers have concluded that because of the difficulty of proving discriminatory intent, potential plaintiffs often decline to file discrimination claims. ${ }^{165}$

In addition, the intent requirement fails to address unconscious racespecific government action, ${ }^{166}$ and, a fortiori, it cannot handle what I call transparently race-specific decisionmaking. ${ }^{167}$ The narrow conception of "racism" embodied in the intent rule forestalls serious consideration of the dynamics of institutional and cultural racism, ${ }^{168}$ at least in the context of constitutional litigation. To the extent that these latter varieties of race "discrimination" have becone the dominant mechanisms for maintaining white supremacy, the intent requirement renders constitutional race discrimination law increasingly unhelpful in achieving racial justice. ${ }^{169}$ This conclusion is especially troubling in light of the Fourteenth Amendment's clear focus on the problem of race and racisn. ${ }^{170}$

Similarly, the rule that mandates strict judicial scrutiny of all racespecific government action, regardless of the groups advantaged or disadvantaged by it, is counterproductive when viewed from the perspective of substantive racial justice. Strict scrutiny makes it exceptionally difficult to construct even modest government programs aimed at the lingering effects of past societal discrimination, not to mention more broadly conceived efforts to achieve some measure of distributive racial equality. ${ }^{171}$ The Croson rule effectively ties the government's hands in this regard. ${ }^{172}$ Of

that the disparate effects-all but a few of the city's black residents were excluded under the new plan-established discriminatory intent. Id. at 347.

165. Theodore Eisenberg \& Sheri L. Johnson, The Effects of Intent: Do We Know How Legal Standards Work?, 76 CORNELl L. Rev. 1151, 1166 (1991).

166. One scholar who has taken a position to the contrary is Strauss, supra note 75 , at 956-62.

167. See infra notes 177-94 and accompanying text.

168. Institutional racism can be defined as "the maintenance of institutions that systematically advantage whites"; cultural racism is "the usually unstated assumption that white culture is superior to all others." Flagg, supra note 10, at 959 (citing JAMes M. Jones, Presudice ANd RACism 129-31, 14749 (1972)).

169. Criticism of the discriminatory intent rule has been extensive, but one of the more incisive arguments has been made by Charles Lawrence, who faults it for its failure to reach unconscious racism. Charles R. Lawrence III, The Id, the Ego, and Equal Protection: Reckoning with Unconscious Racism, 39 STAN. L. REv. 317 (1987); see also Flagg, supra note 10, at 967 n.66 and sources cited therein.

170. I know of no one who would deny that problems of race are central to the history of the Fourtecnth Amendment, though many argue that the broad language of the Equal Protection Clause justifies its application to matters other than race discrimination as well.

171. Arguments advocating "affirmative action" on distributional grounds can be found in $T$. Alexander Aleinikoff, A Case for Race-Consciousness, 91 Colum. L. Rev. 1060 (1991); Derrick A. Bell, Jr., Bakke, Minority Admissions, and the Usual Price of Racial Remedies, 67 CaLIF. L. REv. 3 (1979); Owen M. Fiss, Groups and the Equal Protection Clause, 5 PHIL. \& PuB. Afr. 107 (1976); Johnson, supra note 162; Duncan Kennedy, A Cultural Pluralist Case for Affirmative Action in Legal Academia, 1990 Duke L.J. 705; Randall Kennedy, Persuasion and Distrust: A Comment on the Affirmative Action Debate, 99 HaRv. L. REv. 1327 (1986); Kathlecn M. Sullivan, Comment, Sins of Discrimination: Last Term's Affirmative Action Cases, 100 HaRv. L. Rev. 78 (1986).

172. Again, criticism of the Court's strict scrutiny rule is voluminous, but much of the debate was published before Croson was decided. As usual, Pat Williams sets forth a unique, and uniquely helpful, 
course, it must be stated again that process theory in its best aspect tends to approve such measures and to disapprove the judicial activism that would invalidate them, but it is also true that the process perspective encourages adherence to a principle of colorblindness that has outlived its utility as a vehicle for fostering substantive racial equality. ${ }^{173}$ At best, the record of the process perspective on the "affirmative action" front is mixed.

Together, the discriminatory intent and strict scrutiny doctrines situate constitutional race discrimination law as a formidable adversary to the cause of substantive racial justice. Clearly, less regressive doctrines can be, and have been, formulated. Charles Lawrence has proposed an analysis of disparate impact cases, for example, in which heightened judicial scrutiny would turn on the question of whether a facially neutral action had "racial meaning" in the dominant community. ${ }^{174}$ This sort of approach reaches the most egregious instances of unconscious racism, but stops short of mandating heightened scrutiny in all disparate impact cases. Similarly, "benign" race-specific action might trigger some intermediate form of judicial scrutiny, rather than the "strict" review mandated under current doctrine. ${ }^{175}$ The process perspective has contributed to the movement away from these and similar progressive proposals in the complex manner described herein, and to that extent has been a factor in the "deradicalization" of constitutional race discrimination law. ${ }^{176}$

III

\section{Transparency and Process}

This Part sets forth the argument that the process perspective is transparently white. In order to make that case, I first outline the transparency thesis. I then extend the transparency concept from criteria of decision, the context in which it was first developed, to theoretical enterprises, such as the processual stance that is the subject of this Article. This extension requires elaboration and evaluation of the senses in which theory might be said to be "white." Finally, I explore the normative implications of the conclusion that the process perspective is in fact, in every relevant sense, transparently white.

perspective in Patricia Williams, The Obliging Shell: An Informal Essay on Formal Equal Opportunity, 87 Mich. L. REv. 2128 (1989); see also sources cited in Flagg, supra note 10, at 1009 n.199.

173. Flagg, supra note 10, at 954-55.

174. Lawrence, supra note 169 , at $324,328,355-62$.

175. See, e.g., Justice Brennan's position in Regents of the Univ. of Cal. v. Bakke, 438 U.S. 265, 356-62 (1978) (Brennan, J., concurring in the judgment and dissenting in part) (arguing that the Court should engage in heightened review of racial classifications employed for benign purposes, but that sueh review should not be " 'strict' in theory and fatal in fact").

176. See sources cited supra note 75 . 


\section{A. The Transparency Thesis}

The transparency thesis begins with the proposition that white people tend not to be conscious of whiteness; when whites interact with whites, race is a transparent characteristic. ${ }^{177}$ This does not mean that whiteness is socially irrelevant, but rather that it is relegated by whites to the level of the subconscious. Because whiteness is the social norm, whites tend to equate it with racelessness.

The transparency phenomenon casts doubt on the concept of race-neutral decisionmaking. Because whiteness itself is transparent, personal characteristics associated more closely with whites than with non-whites are more likely to be perceived by whites as race-neutral than as race-specific. Consider the story of David, a black law student who graduated recently from a top-ten law school. ${ }^{178}$ During his years in school, David was an extremely active participant in class discussions, who generally focused on questions concerning the ways a rule or policy had affected, or prospectively might affect, black people and other racial minorities. He acquired a reputation as a "gunner," 179 but with a special twist: the white students tended to see him as someone who was only interested in "race stuff," not law. David was an excellent student who ultimately graduated in the top $10 \%$ of his class. During his second year, when both his academic potential and his interest in racial justice already were evident, he apphed for postgraduation federal judicial clerkship positions. One of the letters of reference written for him by a member of the law faculty read in part: "David has shown great conceru with problems of racial equality, both in and outside the classroom. In general, I have found that these interests don't interfere with his ability to engage in legal analysis."

By implication, David had been characterized as too "political" to be a good law clerk. This assessment accepts as a given the proposition that matters of race are peripheral to good legal analysis. It is a view that is distinctively, but transparently, white because white people generally lack any incentive to regard issues of "race" as central ones. ${ }^{180}$ In comparison with the typical white's marginalization of race, David's level of interest appears almost a preoccupation. From the perspective of his social experience, however, legal analysis ought to begin with the existing racial maldistribution of social and material goods.

As this example illustrates, the notion of transparently white race-specific decisionmaking calls for some consideration of what it means for a

177. The transparency thesis is set forth more completely in Flagg, supra note 10, at 969-79.

178. This is largely a "made-up" story, though it's based on an actual letter of "recommendation" written by a member of a law faculty on behalf of a law student applying for a judicial clerkship. 1 name the character David in memory of my dear friend David Susky, who died of AIDS.

179. This term is used by law students to describe a student who participates frequently-in others' view, too frequently-in classroom discussions.

180. As members of the numerically dominant social group, white people are in a position to externalize race: for whites, mentioning "race" calls up images of people of color, not of whites. 
criterion of decision to be "white." When I first developed the transparency thesis, I argued that attempting to formulate a universal technique for distinguishing genuinely race-neutral criteria of decision from those that only appear neutral should not be our first priority in confronting the transparency phenomenon. ${ }^{181}$ I suggested instead that whites adopt an attitude of deliberate skepticism toward ostensibly race-neutral criteria of decision. Such an attitude would foster the development of various prophylactic measures, such as the adoption of pluralistic criteria of decision. ${ }^{182}$

I continue to believe that the skeptical stance represents the most secure method currently available for whites who wish to address the transparency phenomenon in their own decisionmaking. Substituting a theoretical or categorical approach for the more fluid presumption against accepting ostensible race-neutrality at face value would be a mistake at this early stage in the attempt to analyze the transparency phenomenon. However, it would not necessarily be harmful to begin to explore the factors that make a criterion of decision "white," so long as that inquiry does not wholly displace skepticism toward apparently race-neutral decisionmaking.

With that cautionary note, I offer some preliminary thoughts on what it means for a criterion of decision to be "white" from the perspective of the transparency phenomenon. ${ }^{183}$ First, it is apparent that the characteristic in question must be statistically associated with white people to a greater extent than with non-whites. A facially race-neutral characteristic that is evenly distributed across races (and also is perceived by whites to be evenly distributed) does not have much potential to take on a race-speciflc connotation or usage. ${ }^{184}$ Some degree of differential distribution is a necessary condition of "whiteness."

Statistical "whiteness" is not by itself sufficient to render personal qualities "white" in the sense with which transparency analysis is concerned. A second requirement is that the quality in question be one that is

181. Flagg, supra note 10 , at $977-79$.

182. I use "pluralistic" here in the sense of cultural, not interest-group, pluralism. For further elaboration of this concept, see Gary Peller, Notes Toward a Postmodern Nationalism, 1992 U. ILL. L. Rev. 1095; Gerald Torres, Critical Race Theory: The Decline of the Universalist Ideal and the Hope of Plural Justice -Some Observations and Questions of an Emerging Phenomenon, 75 MinN. L. Rev. 993 (1991); Patricia J. Williams, Metro Broadcasting, Inc. v. FCC: Regrouping in Singular Times, 104 Harv. L. Rev. 525, 528-33 (1990); Kevin M. Fong, Comment, Cultural Pluralism, 13 Harv. C.R.-C.L. L. REv. 133, 136-37 (1978).

183. When the decisionmaker ascribes to the individual under evaluation a label carrying negative connotations, it's the underlying norm, rather than the label itself, that I characterize here as "white." For example, in the story recounted earlier, it is the implicit norm of apolitical reasoning that is "white."

184. A characteristic distributed eveniy across races, but nevertheless regarded by whites as associated more strongly with one race or another, would by definition not be transparent; its (perceived) racial specificity would be apparent.

185. Because, by definition, the "whiteness" of transparently white characteristics is not consciously noticed by white people, the statistical correlation of a given characteristic and whites will not be obvious. The relevant inquiry, then, is whether, on reflection, one can discern the requisite racial distribution. 
regarded favorably by whites. Transparency analysis is designed to identify instances of suppressed race-specific decisionmaking that operate to disadvantage non-whites. ${ }^{186}$ That objective would not be furthered by including within the scope of "whiteness" characteristics that are associated with white people but viewed negatively; the notion of "whiteness," for transparency purposes, must include an element of positive regard. ${ }^{187}$

In the example set forth above, the black law student engaged in overtly race-related behavior that was measured against a transparently white standard; it is relatively easy to uncover the hidden race-specificity in that case. A similar transparency analysis applies as well to behavior patterns that are not outwardly associated with race, but which whites regard as "neutral." Consider the case of a black woman bank employee whom I will name "C.W."188 C.W. worked at the Big Bank, a predominantly white institution located in a white neighborhood, for eight years. During that time, she was successively promoted from an entry-level position, to drivein bank teller, to lobby teller, and finally to commercial teller. However, during the last year of her employment, C.W. unsuccessfully sought promotion four times to supervisory positions, each of which was awarded to a white employee.

The Bank relied on C.W.'s performance evaluations in justifying the decisions not to promote her. These evaluations required supervisors to rate employees in a number of categories, such as attendance, drive, and ambition. However, supervisors tended to focus on a single category: leader-

186. Because the objective is racial justice, there is no need for a theory that would address covertly race-specific criteria of decision that operate to disadvantage white people. Furthermore, the transparency phenomenon is itself race-specific. Only whites have the social power that renders racespecific norms "raceless." See Flagg, supra note 10, at 1006.

187. Of course, there may be no white-specific negative characteristics. Qualities that are in fact statistically "white" likely take on positive connotations for that reason alone.

188. Title VII aficionados will discern a resemblance between these facts and those of Watson v. Fort Worth Bank \& Trust, 487 U.S. 977 (1988). In that case, Clara Watson filed a race discrimination claim under both the disparate treatment and disparate impact models of Title VII. Her individual disparate treatment claim was resolved in the Bank's favor by the United States Court of Appeals for the Fifth Circuit. Watson v. Fort Worth Bank \& Trust, 798 F.2d 791 (5th Cir. 1986), vacated and remanded, 487 U.S. 977 (1988). Watson's disparate impact claim made its way to the Supreme Court, where a majority of the Justices agreed that disparate impact analysis can be applied to "subjective" criteria of decision. 487 U.S. at 990-91. On remand, the case appears to have been settled.

Clara Watson's case presents difficult issues under existing Title VII and transparency analyses that are outside the scope of this Article. However, I choose the oblique reference to her, by borrowing selected facts from her situation, because I see in her case an instance of transparency at another level. Contrast Clara Watson's litigation endeavors with those of Ann Hopkins, who filed a Title VII sex discrimination claim that at the trial stage seemed to present issues regarding subjective criteria of decision that were very similar to those raised in Watson's case. Price Waterhouse v. Hopkins, 490 U.S. 228 (1989). Hopkins was a well paid, white senior manager at the time she failed to make partner at Price Waterhouse; in her case the Supreme Court reached out to find a basis for a disparate treatment claim. The difference may be attributable in part to the availability of indirect evidence of sex discrimination in Hopkins' case; similar evidence of race discrimination may be harder to come by. In addition, I speculate that the Court may find unconscious sex discrimination easier to recognize than unconscious race discrimination. 
ship potential. In each of the four instances in which C.W. was denied promotion, she was rated poorly on "leadership potential" by her white supervisor.

Suppose that C.W. was in fact less apt to assume control of a situation than her white co-workers, and that she was less likely to express herself in a commanding way than the white men and women who were her supervisors at the bank. By hypothesis, then, the judgment of C.W.'s evaluator was correct: she did not exhibit the personal characteristics that in the past had been used to identify good candidates for supervisory positions. The criterion of decision used here was apparently race-neutral; this example has been constructed to exclude the effects of bias or stereotyping.

Nevertheless, it is clear that expectations had been formed that were statistically associated with whiteness. ${ }^{189}$ C.W.'s relative lack of assertiveness might be explained by the fact that the Bank was a predominantly white environment in which black people generally were expected to conform to white cultural norms. Perhaps C.W. acquired habits of relative passivity as a survival technique; in fact, those behaviors niay have accounted for her previous promotions. In a world that unconsciously expected black submissiveness, the standard of "leadership" and assertiveness against which C.W. came to be measured was functionally white.

In this example, the effects of race on the decisionmaking process were reflective of the cultural oppression of blacks. One might also construct a scenario in which C.W.'s relative passivity was the result of cross-cultural difference; it is not difficult to imagine a culture with different expectations regarding leadership styles. In this variant of the hypothetical, the whiteness of the applied standard would be attributable to cultural variation, but not necessarily to background cultural oppression. In either case, the norm applied would be transparently white.

The goal of this sort of transparency analysis is to raise the question of assimilationism. ${ }^{190}$ When white decisionmakers employ transparently white criteria of decision, they pose for non-whites a choice between assimilation and exclusion. ${ }^{191}$ However, it is not obvious that whites do so only in circumstances in which they have carefully and thoughtfully rejected pluralist objectives and/or pluralist means of achieving them. ${ }^{192}$ More than likely, a good part of the time white decisionmakers employ familiar, transparently white criteria of decision out of habit. However, such inertia is not a sufficient reason for maintaming the existing racially inequitable distribution of societal goods. As Derrick Bell has suggested, continuing white

189. Obviously, the characteristics associated with whiteness were regarded favorably; C.W. was denied prontotion because she lacked them.

190. By "assimilation" 1 mean assimilation to white cultural norms, behaviors, and expectations.

191. For a discussion of the ways assimilationism impacts norms of equality and individual autonomy, see Flagg, supra note 157, at 277-87.

192. Again, I use "pluralism" in the sense of cultural pluralism. See supra note 182 and sources cited therein. 
indifference to the effects policies have on blacks is a form of racism that is as harmful as the overt disadvantaging of blacks permitted during the long period of legalized apartheid in this country. ${ }^{193}$

Transparency analysis, then, aims to foster open discussion of the merits of the criteria of decision we actually employ. It may be that in some cases we will choose to keep the transparently white standards that are currently in place, but I suspect that in many more instances we will recognize pluralist means of achieving existing, or only slightly modified, goals. In either case, attempting to ascertain the extent to which existing criteria of decision are transparently white can only be beneficial to the cause of racial justice. ${ }^{194}$

\section{B. The Transparency of the Process Perspective}

The preceding discussion explicates the basic notion of transparency and its impact on our assessment of ostensibly race-neutral white decisionmaking, but does not resolve the question that is the central concern of this Article-the sense in which the process-oriented approach to constitutional race discrimination law can be said to be transparently white. This inquiry attempts to extend the transparency thesis to a new dimension in its application to theories or intellectual paradigms. This expansion of the transparency thesis takes the criteria of "whiteness" set forth above as its points of departure.

It is evident that a theory must have been formulated with significant participation by white people if it is to be considered "white" for the purpose of transparency analysis. This is analogous to the requirement that a characteristic employed as a criterion of decision have a statistical association with white people. A theory constructed without meaningful input by whites would be similar to a personal characteristic evenly distributed across races-there would be no opening for the trait or theory to take on a white-specific dimension.

However, it should be noted that some participation by non-whites would not defeat this element of the claim that a given theory is "white." Non-whites often join white-dominated enterprises for a variety of reasons, ranging from survival to the judgment that a particular project is worthwhile for its own sake. Therefore, the requirement here is that a theory liave been formulated predominantly by white theorists.

It should be apparent that development by white people is not a sufficient condition for characterizing a theory as "white" for transparency purposes. In addition, the theory in some respect must operate to the advantage of whites. Again, this requirement parallels one of those that identify a

193. Derrick Bell, Faces at the Bottom of the Well: The Permanence of Racism 1-14 (1992).

194. I reiterate that my first choice would be adoption of a skeptical stance that would look into the question of assimilationism whenever whites formulate or apply criteria of decision. 
criterion of decision as transparently white. There would be little point in seeking to uncover, as an instance of transparency, a trait or theory that functions in a race-neutral manner, or in a way that advantages non-whites. I have argued elsewhere that criteria of decision that in fact operate to benefit non-whites never partake of transparency; the conflict they present with the interests of the dominant white majority assures that their race-specificity will not go unremarked. ${ }^{195}$ Even if there were a case to be made for the hidden race-specificity of some theory or criterion of decision that disadvantages whites, however, uncovering those instances of race-dependency is not the object of the transparency inquiry.

In conjunction, satisfaction of these two requirements-that a theory or criterion of decision be formulated predominantly by whites and that it operate in practice to the advantage of whites-seems sufficient to support a characterization of "whiteness." 196 Nevertheless, some might argue that this amounts to no more than a reduction of the notion of "whiteness" to disparate impact and that some additional element that more closely links cause (the theorists or decisionmakers) to effect should be required. One obvious candidate is a requirement of discriminatory intent. However, it should be apparent that an "intent" element would be misplaced because it would undermine the notion of transparency itself. Transparency is a form of unconscious racism. With respect to criteria of decision, therefore, the existence of racially disparate effects alone ought to be sufficient to trigger skepticism concerning the race-neutrality of particular criteria of decision. ${ }^{197}$ Similarly, a judgment that a theoretical enterprise is transparently white cannot turn on an assessment of the theorist's state of mind. If one required evidence of the theorist's intent to favor whites, there would be no need for a transparency analysis. ${ }^{198}$

Moreover, this Article does not set out to show that white theorists are personally responsible for the undesirable effects of the process perspective; the enterprise is to locate responsibility in the theoretical stance itself. Accordingly, the appropriate paradigm is to be found in a structural, rather

195. Flagg, supra note 10, at 1006.

196. That is, satisfaction of these two criteria is sufficient to justify examination of assimilationism. See infra text accompanying notes 203-09.

197. However, the existence of racially disparate effects ought not be a necessary condition of a transparency inquiry; the white decisionmaker who is determined to address the transparency phenomenon will regard all facially neutral criteria of decision formulated or deployed by whites as presumptively race-specific. See Flagg, supra note 10, at 993 . Nevertheless, racially disparate effects are evidence that the presumed white-specific criteria have had concrete consequences. Id. at 993-94.

198. A similar argument would apply even if the rule was, as Justice Stevens once suggested, that one is deemed to have intended the foreseeable effects of his acts. See Washington v. Davis, 426 U.S. 229, 253 (1976) (Stevens, J., concurring). If the racially disparate consequences of using a particular criterion of decision were foreseeable to whites, it would be hard to characterize that criterion as transparent. 
than intent-based, conception of racism. ${ }^{199}$ In particular, some theoretical enterprises may be understood as instances of institutional racism, defined as the maintenance of institutions that systematically advantage white people. $^{200}$ Therefore, the final component in the characterization of a theory as transparently white will be a requirement that it be shown to operate systematically to the advantage of whites.

It is evident that the process perspective is transparently white in each of the three senses just described. First, it reflects the work of white scholars. As recounted earlier, the dual strands of the process perspective consist of the philosophy of judicial restraint, and attention to evaluation of institutional processes of decisionmaking. The leading contributors to the elaboration of each strand were white; no evidence suggests that black scholars had any input. Demographically, the process orientation is the brainchild of white theorists alone.

Second, the case has been made in Part II that the process perspective has influenced constitutional race discrimination law to the disadvantage of non-whites. ${ }^{201}$ In particular, the processual stance has cast pervasive doubt on the legitimacy of judicial review, and it has contributed to a climate of discourse in which processual analyses displace substantive constitutional interpretation. In turn, these distinct strands of the process perspective eacl have pushed the Court in the direction of two of its most racially inequitable constitutional doctrines: the discriminatory intent requirement and the rule that all race-specific government action triggers strict scrutiny.

Finally, the impact of the process perspective on this undesirable evolution of constitutional race discrimination law has been systematic rather than accidental. I argued in Part II.A that recognition of the "counter-majoritarian difficulty" militates in favor of the conception of equality that is traditional in our society-that is, the view that most closely approximates that of the white majority. Similarly, in Part II.B, I contended that the process-theoretical evaluation of institutionally appropriate processes of decisionmaking would validate the colorblindness, but not the antisubordination, interpretation of the constitutional equality guarantee. Thus, whatever the extent of the process perspective's influence on constitutional doctrine, that infuence inevitably is in the direction of one conception of equality.

199. "Racism" may seem a harsh term, even with the understanding that no attribution of personal blame is intended. However, the one viable alternative, "institutional maintenance of white supremacy," seems hopelessly unwieldy.

200. See James M. Jones, PreJudice AND RACism 129-31 (1972). Jones acknowledges the possibility that institutional racism may be unconscious. Id. at 131 . In some cases, theories might exhibit cultural racism as well. See id. at I47-49.

201. See supra text accompanying notes 160-76. 
In sum, the process perspective is thoroughly white. ${ }^{202}$ It was formulated by white people, and it has had a significant and systematically adverse impact on the fortunes of non-whites in the development of race discrimination doctrine. The conclusion that the process perspective ought to be viewed as white, however, does not end the transparency inquiry. As is the case with transparently white criteria of decision, it may be that the assimilationism entailed by normative whiteness is justifiable on other grounds. The next Section explores that possibility.

\section{The Import of Whiteness}

Analysis of the question whether a transparently white norm is worth preserving once its whiteness has come to light requires that one strike a balance between two competing considerations. On the one side, there is the nature of the plurahst interest that is depreciated by the imposition of an assimilatiomist norm. On the other side of the balance, however, lies the substance of the norm itself. One might conclude that certain objectives are worth pursuing even at the cost of imposing on some individuals norms they do not share or to which they do not desire to conform. ${ }^{203}$

The processual approach to constitutional law implicates the aspect of cultural pluralism that is concerned with the ways social experience varies in parallel with one's position in the social hierarchy. With respect to race discrimination, for example, the "victim" perspective ${ }^{204}$ understands as discriminatory the material and social conditions of everyday life that constitute the existing racial hierarchy, without regard to the specific acts of identifiable individuals. In contrast, the "perpetrator" perspective, associated with members of the dominant racial group, tends to regard the existing social order as natural and just; only conscious departures from prevailing norms are deemed blameworthy instances of discrimination. These different concepts of "discrimination" can be traced to differences in social experience: members of groups occupying socially subordinate positions are much less likely than whites to regard intent as an integral compo-

202. It probably hasn't escaped the thoughtful reader's attention that arguments similar to those establishing the race-specificity of the process perspective could be made with respect to gender, sexual orientation, and class, at mininun. I concede the point, but with two caveats. First, the case has to be made independently in each instance for the existence of harmful effects fiowing from the infiuence of the process perspective. Second, race is uniquely central to the Fourteenth Amendment's equal protection guarantee. Therefore, the tension betwecn the process perspective and substantive constitutional commands is at its highest with respect to race discrimination issues.

203. See Flagg, supra note 157, at 279.

204. The terminology is Alan Freenuan's. See Freeman, supra note 87, at 1052-57 (comparing the "perpetrator" perspective with the "victim" perspective). This characterization is suggcstive of the more recent debate on the question of racial "voice." See, e.g., Colloquy, Responses to Randall Kennedy's Racial Critiques of Legal Academia, 103 Harv. L. Rev. 1844 (1990); Randall L. Kennedy, Racial Critiques of Legal Academia, 102 HARv. L. REv. 1745 (1989) (discussing the intellectual contributions of scholars of color); Mari J. Matsuda, Looking to the Bottom: Critical Legal Studies and Reparations, 22 HARV. C.R.-C.L. L. Rev. 323, 324 (1987) ("those who have experienced discrimination speak with a special voice to which we should listen"). 
nent of racial harm. ${ }^{205}$ In this instance, therefore, cultural difference is at least partially the product of cultural stratification.

"Assimilationism" refers to the socially- or legally-created obligation to conform to norms other than one's own. In general, only dominantgroup norms can be assimilationist; by definition, subordinate groups lack the social power to impose their norms on members of the dominant group. ${ }^{206}$ Thus, for example, C.W. ${ }^{207}$ was held to assimilationist norms to the extent that her behavior and interactive style were judged according to standards of assertiveness adhered to by members of the dominant racial group, who, unlike C.W., do not have to be concerned with the reactions of persons occupying a "higher" position in the social hierarchy. ${ }^{208}$ In C.W.'s situation, cultural pluralism would mandate an exploration of the ways in which the demands of the supervisory positions at issue could be met by someone with a "black," rather than a "white," cultural style. ${ }^{209}$

The pluralist interest impaired by process-oriented constitutional law is the interest in antisubordinationist modes of analysis. These days, all who enter the constitutional arena must speak the processual language of institutional concerns. However, because the process perspective systematically exerts pressure in the direction of the colorblindness interpretation of equality, the arena is not equally hospitable to all points of view. Those for whom matters other than institutional legitimacy take priority must nevertheless confront the substantive "tilt" associated with the process perspective. 210

However, the ultimate assessment whether the process perspective is justifiably assimilationist must weigh its benefits against its costs. This might be a difficult task if the process perspective lived up to its promise to place the evaluation of legal reasoning on a value-neutral foundation. Had that enterprise been successful, one would have had to choose which of two, arguably equally attractive, alternative values should take precedence:

205. See supra note 92 and accompanying text.

206. There may be rare exceptions; circumstances in which a white person is attempting to integrate into a predominantly black environment may provide one example.

207. See supra text accompanying notes 188-89.

208. I anticipate a possible objection here that everyone, in some sense, has to answer to someone else. However, the contention is that whites occupy the uppermost position in this society's racial hierarchy, and accordingly do not have to take account of the expectations of members of other racial groups in the same way that members of those groups have to accommodate the expectations of whites. For arguments advocating pluralism based on equality of respect, see Kenneth L. Karst, Paths to Belonging: The Constitution and Cultural Identity, 64 N.C. L. Rev. 303 (1986); Mari J. Matsuda, Voices of America: Accent, Antidiscrimination Law, and a Jurisprudence for the Last Reconstruction, 100 YALE L.J. 1329 (1991).

209. I emphasize that I do not assume there is just one "white" or "black" cultural style; I mean only to refer to differences in style that can be attributed to one's position in the racial hierarchy.

210. This "tilt" predominantly, but not exclusively, affects non-whites, who must cope not only with structural racism, but with a legal system that fails to take their own understanding and analysis of race discrimination seriously. 
the institutional values embodied in the process perspective, or substantive racial justice. ${ }^{211}$

Perhaps fortunately, one does not have to make that decision, because the process perspective does not deliver the neutrality it promises. ${ }^{212}$ It predisposes constitutional analysis in the direction of an equality principle that favors the status quo of white supremacy. Thus, the defense that assimilationism is in order here because larger values are served by the process perspective is not persuasive, since the claimed objective of the processual stance has not been attained. I conclude then, that in the interest of racial justice the process perspective should not continue to enjoy its central, preferred position in constitutional discourse.

It might now be worth speculating briefly on the shape the constitutional landscape might assume were the institutional concerns associated with the process perspective removed from the picture. The most likely candidate to replace process-based approaches at center stage of constitutional theory is textualism. ${ }^{213}$ Even "open-ended" constitutional provisions, ${ }^{214}$ such as the Equal Protection Clause of the Fourteenth Amendment, are constitutional texts after all; the Reconstruction framers almost certainly contemplated the exercise of the power of judicial review, and chose the constitutional language they did accordingly. The process perspective aside, there is no compelling reason not to get on with the (admittedly difficult) task of substantive constitutional interpretation.

However, one must ask whether a more explicitly normative debate over the meaning of "the equal protection of the laws" would produce results more favorable to non-white interests than is currently the case. The strongest argument supporting optimism on this point is the weakness of the prevailing colorblindness principle: of the widely recognized possible interpretations of the Equal Protection Clause, the colorblindness principle has probably the weakest historical and moral foundation of all. ${ }^{215}$ Fuller consideration of its merits, without interference froin the process perspective's institutional concerns, might well relegate the colorblindness interpre-

211. For some, of course, even this choice would not be difficult. As Charles Lawrence puts it, "[T]o give judicial economy priority over the recognition of constitutional injury seems wrong. It is to make a value choice that is no different from the decision to deny that injury recognition altogcthcr." Lawrence, supra note 169, at 384.

212. Nevertheless, processual approaches retain considerable appeal. Paul Brest found their persistence "not at all puzzling. [Process theories] are to constitutional theory what the perpetual motion machine is to science. Hope springs eternal." Brest, supra note 66, at 141-42.

213. See, e.g., United States v. Carolene Products Co., 304 U.S. 144, 152 n.4 para. 1 (1938); see also supra note 52.

214. Ely rejected the text-based justification for judicjal review on the ground that the meaning of the Constitution's "open-ended" provisions is too indeterminate to overcome the counter-majoritarian diffieulty. ELY, supra note 32, at 41.

215. See Flagg, supra note 10, at 1006-14 (arguing that the colorblindness principle is not easily justified on the basis of the constitutional text, precedent, or instrumental values, and that it is morally problematic). 
tation to a more appropriate, less central position in the constitutional debate.

One ought not be too sanguine about the potential for more equitable constitutional doctrine in the absence of the processual influence, however, even if it is correct to assert that the latter has been a significant factor in the adverse development of the doctrine now in place. The point has been made most compellingly by Derrick Bell: whites always are ready to sacrifice blacks when white interests so dictate. ${ }^{216}$ The inherent indeterminacy of doctrine guarantees that avenues of revision always are available, no matter what substantive advances appear to have been made. ${ }^{217}$

If the process perspective has been a culprit in the formation of existing constitutional race discrimination law, then disavowing it will not necessarily repair the problem. What is needed is a deeper commitment to racial equity itself, independent of the particular constitutional or other legal norms a particular moment in history might demand. That sort of fundamental alignment with the cause of racial justice likely would have forestalled formulation of the process perspective in the first place.

Nevertheless, though dismantling the symptom does not automatically constitute a cure, thoughtful examination of the symptom's internal structure is valuable. White people who wish to resist racial hierarchy need to achieve a detailed understanding of the contours of institutional racism, and the race-specificity of the process perspective provides a prime example of the way that form of racism works. Studying the intellectual paradigms we unwittingly employ as participants in the maintenance of white supremacy places us in a better position to avoid similar errors in the future.

\section{ConCLusion}

In this Article I have leveled two charges against the process perspective: that it has contributed to the post-Brown inovement of constitutional race discrimination law in a direction adverse to the interests of substantive racial justice, and that it is transparently "white." We ought to try to wean ourselves, as constitutional scholars and judges, of the preoccupation with processual inatters that has helped obscure our vision of racial justice. At the same time, I acknowledge that the process perspective is in many respects an "enduring principle" of constitutional law, one that will not easily be displaced by the force of this or any other reasonably foreseeable critique. Consequently, I anticipate that some readers might question whether the game is worth the candle.

Certainly, the objective here has not been to foster white guilt, which generally functions only to solidify the racial status quo. Guilt tends to lead to a form of paralysis in which white people seem unable to analyze for

216. See Derrick A. Bell, Jr., Racial Remediation: An Historical Perspective on Current Conditions, 52 Notre DAME L. Rev. 5, 6 (1976) ("white self-interest will prevail over black rights").

217. For an especially persuasive presentation of this thesis, see Seidman, supra note 75. 
ourselves the causes, dynamics, or potential responses to existing forms of racism. Instead, we tend to look to people of color for analysis and explanation, ultimately concluding that the problems are so overwhelming that there is little or nothing we, as individuals, can do. Both the reliance on non-whites as the ultimate source of our understanding of contemporary racism, and the assessment that change is difficult or impossible, operate to reinforce the racial status quo. We retain our privileged position intellectually by insisting that others explain racism to us, and materially by refusing to search out ways to participate in the process of change.

Accordingly, a central goal of this Article has been to engage white readers in the project of taking some responsibility for institutional and cultural racism. One component of that endeavor is to try to understand the experiences and perspectives of others. The analysis here of the process perspective's negative impact on constitutional race discrimination doctrine is an attempt to view processualism through others' eyes. White readers might seize this occasion as well to reflect on what it might be like to participate in a universe of intellectual discourse not of one's own making, to contend for "constitutional rights" in an environment constructed by thinkers who seem oblivious to the way race and racism appear to oneself. At some level, enduring such a "foreign" intellectual paradigm must be a difficult and disorienting experience.

The second, and perhaps more crucial, element in the white responsibility project is to come to understand ourselves as white. Rethinking our racial specificity may help us see whiteness as just one race among many; it may open an avenue for us to envision ourselves as, and thus to become, partners in a culturally pluralist community. The alternative, it seems to me, is to hold fast to our place at the top of the existing racial hierarchy, and so to continue to benefit from the very sort of unearned privilege liberal ideology purports to disapprove. Characterizing the process perspective as distinctively white, then, is designed to unsettle the seemingly secure foundations of present-day constitutional discourse, and to propose that we begin again, this time in a more pluralist vein. In constitutional law, it may be that nothing short of dismantling the covertly race-specific institutional premises of the processual stance can constitute a first step in the direction of meaningful change. 